\title{
DEACON CORESI (C. 1510 - C. 1583) \\ AND HIS ACTIVITY AS A PRINTER IN THE CONTEXT OF THE 16TH CENTURY PROTESTANT PROPAGANDA*
}

\author{
TRANSLATED BY THE AUTHOR IN ENGLISH
}

\author{
Assoc. Prof. PhD. Ion Marian CROITORU, \\ Faculty of Orthodox Theology and Education Sciences, \\ Valahia University of Târgoviște, \\ ROMANIA \\ E-mail: ioncroitoru@yahoo.fr, im.croitoru@yahoo.gr
}

\begin{abstract}
The biographical data about the life of deacon Coresi (Coressius) are extremely few and it has been admitted, after many debates, studies and analyses, that he was from Târgoviște, it is supposed that he joined a school in Slavonic at Dealu Monastery, and that he was the owner of a printing press, yet standing out as a skillful printing master. It is also known that he had a son, called Șerban, whom he taught the art of the printing press. The name of deacon Coresi is mentioned in the books he had printed in Brașov (during two periods: 1556-1557; 1560-1583, at irregular intervals), Târgoviște (1557-1558), Alba Iulia (1567-1568) and SasSebeș (1580), during five great periods (1556-1558, 1559-1565, 1566-1570, 1571-1577, 1578-1583), in Romanian and Slavonic. Thus, by his activity, deacon Coresi contributed to the introduction of the Romanian language in the cult of the Orthodox Church of the Romanian Countries, but also in the use of the princely administrative offices of the extra-Carpathian Romanian Countries. Following the discussions around the thesis called "the inner impulses" compared to the thesis of the "influences from the outside", many Romanian scholars and researchers are convinced that the phenomenon of introduction of the Romanian language in the official use of the Church and of the Reign does not represent an initiative under the exclusive patronage of the protestant propaganda but rather "an action based on a Romanian, Orthodox initiative, a page of internal history", without being ignored, nevertheless, the fact that the first printings in the Romanian language appear in the environment of Transylvania, preoccupied by the ideas of the Reformation, which also imposes the observation that the activity realized by deacon Coresi, especially in Brașov, does not occur independently from the principles promoted by the Reformation. As far as the formation of the Romanian unitary literary and liturgical language is concerned, one can admit that this process begins with Coresi's printings, even though the acceptance of the
\end{abstract}

\footnotetext{
* This study is a translation by the author in English. For the first version of this study in Romanian, with the same title, see Diaconul Coresi - ctitor de limbă română, misionar al credinței străbune și slujitor devotat al neamului românesc, Editura Arhiepiscopiei Târgoviștei, Târgoviște, 2017, pp. 277-328. For the second version, but improved, in Romanian, see Mitropolia Olteniei, no. 69 (821-824)/5-8 (2017), pp. 68-112, which was translated by author in English, with a small change to the title.
} 
Wallachian dialect as the only Romanian norm will happen later, according to the specialists, namely by the middle of the 18th century. However, both for the initiation of the respective process, and for the fact that Coresi's printings represent the first texts printed in the Romanian language, constituting, therefore, "the material support from which the study of the Romanian literary language began", deacon Coresi is "rightly" called "the father of the Romanian literary language". Consequently, the protestant propaganda was expecting, through the nationalization of the cult of the Orthodox Church and the printing activity of deacon Coresi, to discover, in the Romanians' conscience, elements able to awaken in them a certain spiritual crisis, which did not happen, because different was the living of the Orthodox faith from all that had been offered, at that time, by the Roman-Catholic doctrine and the outbreak of the Reformation.

Keywords: Reformation, Counter-Reformation, protestant (Lutheran, Calvinist) propaganda, Roman-Catholic propaganda, deacon Coresi (Coressius), cult / worship nationalization;

\section{INTRODUCTION}

The use of the printing press in the Romanian culture bears the mark of the Reign and of the Church, through the initiative of Prince Radu the Great of Wallachia (1496-1508) and through the activity of monk Macarie, coming from Montenegro ${ }^{1}$, who will get to become, according to some researchers, even Metropolitan of the Orthodox Church of HungaroWallachia or Romanian Country $(1512-1521)^{2}$. The first printing press operated, according to the opinion of most researchers ${ }^{3}$, in the precincts of Dealu Monastery, near Târgoviște (1508-1512), so that the princely city of Târgoviște becomes the first printing centre of the Romanians, where they will print, for a start, books in Slavonic, of Middle Bulgarian redaction ${ }^{4}$.

In this city, the printing activity is resumed only during the reign of Ruler Radu Paisie (1535-1545), who called two Serbian artisan printers, Moise the Monk and Dimitrie Liubavici (Dimitrije Ljubavić) the Logothete. They will continue the series of printers in

\footnotetext{
${ }^{1}$ The opinion of many researchers inclines towards the Montenegrin origin, see Lucian Petroaia, "500 de ani de la tipărirea primului liturghier ortodox și a primei cărți pe teritoriul țării noastre: Liturghierul lui Macarie ieromonahul (1508-2008)", in Revista Bibliotecii Naționale a României 14/2 (2008), p. 8; Dana Silvia Țilică, "Ieromonahul Macarie și începuturile tiparului românesc în studii", in Revista Bibliotecii Naționale a României $14 / 2$ (2008), p. 16. In the specialized literature it has been stated that he seems to have been a Wallachian of Montenegro, specifically, of Zeta Voivodate, see Mircea Păcurariu, "Macarie”, in Enciclopedia Ortodoxiei Românești, București, 2010, p. 378; Virgil Molin, "Tradiția artistică a Moldovei în tipăriturile ieromonahului Macarie”, in Mitropolia Moldovei și Sucevei 35/5-6 (1959), p. 305.

${ }^{2}$ Mircea Păcurariu, op. cit., p. 378; Ion I. Croitoru, "Tipografii”, in idem, Ortodoxia și Apusul în tradiția spirituală a românilor. Unitatea Ortodoxiei și apărarea credinței ortodoxe în fața propagandei protestante din secolul al XVII-lea, vol. I, Târgoviște, 2012 (hereinafter: Croitoru, Ortodoxia și Apusul, I), p. 250.

${ }^{3}$ See Victor Petrescu, "Despre primele tipărituri pe teritoriul românesc în secolul al XVI-lea", in Philologia 57 (2015), p. 24; Agnes Erich, Niculina Vârcolici, "Controverse privind tipărirea primei cărți în spațiul românesc. Liturghierul (1508)", in Studii de Biblioteconomie și Știința Informării / Library and Information Science Research 13 (2009), pp. 140-157; Demény Lajos, Lidia A. Demény, Carte, tipar şi societate la români în secolul al XVI-lea. Studii, articole, comunicări, Bucureşti, 1986, pp. 15-55 (hereinafter: Lajos - Lidia Demény, Carte, tipar si societate).

${ }^{4}$ The first printings in this language, attributed to the priestmonk Macarie, were: Sluzhebnik (Hieratikon, 1508), Oktoikh (Octoechos) or Osmoglasnik (1510) and Evangelie (Evangelion) or Chetveroevangelie (Tetraevangelion, 1512), see Bibliografia românească veche, 1508-1830, vol. I, edited by Ioan Bianu and Nerva Hodoş, Bucureşti, 1903, pp. 1, 9 (hereinafter: $B R V, \mathrm{I}$ ).
} 
Slavonic ${ }^{5}$, and in the printing workshop (1544-1551) of Dimitrie Liubavici will be trained the first Romanian disciples (Oprea the Logothete, Peter) ${ }^{6}$, including deacon Coresi (Coressius), servant of the Orthodox Church of Wallachia (Romanian Country) and, later on, of Transylvania ${ }^{7}$. The biographical data about deacon Coresi are extremely few and it has been admitted, following many debates, studies and analyses, that he was from Târgoviște ${ }^{8}$, he is supposed to have followed a school in Slavonic at Dealu Monastery ${ }^{9}$, and to have been the owner of a printing press, standing out, nevertheless, as a skilled printer artisan and being known, however, that he had a son, called Șerban, whom he taught the art of the printing press $^{10}$.

\section{DEACON CORESI'S PRINTING ACTIVITY}

The name of deacon ${ }^{11}$ Coresi appears mentioned, for the first time, precisely as a typographer, in the Epilogue of an Oktoikh, which he finished printing in Slavonic, in Brașov, in 1557, along with another printer, Oprea the Logothete, about whom it is affirmed that he had assumed the patronge of the printing press from Târgoviște ${ }^{12}$. During the same year, deacon Coresi, helped by ten disciples, started printing a Triodion-Pentecostarion in Slavonic (Postnaya Triod-Tsvetnaya Triod), at the request of Prince Pătrașcu the Good of Wallachia (1554-1557) and at the exhortation of the Metropolitan of Hungaro-Wallachia (the canonical name of the Orthodox Metropolitan of Wallachia or Romanian Country) Anania $(1544-1558)^{13}$. The activity related to the printing of the Triodion-Pentecostarion,

${ }^{5}$ See Mircea Păcurariu, Istoria Bisericii Ortodoxe Române, vol. I, Iași, ${ }^{32004, ~ p p . ~ 470-471 ~(h e r e i n a f t e r: ~}$ Păcurariu, Istoria Bisericii, I).

${ }^{6}$ Păcurariu, Istoria Bisericii, I, p. 471.

${ }^{7}$ Ion Gheţie, Al. Mareş, Diaconul Coresi şi izbânda scrisului în limba română, Bucureşti, 1994, pp. 35-36 (hereinafter: Gheție - Mareş, Diaconul Coresi); Adela Otilia Urs, Diaconul Coresi. Monografie și antologie de texte. Teză de doctorat, Cluj-Napoca, 2009, pp. 36, 38, 58, 289 (hereinafter: Urs, Diaconul Coresi). Concerning Coresi's ministry as a deacon, see note 11 below.

${ }^{8}$ Păcurariu, Istoria Bisericii, I, pp. 472, 477; Urs, Diaconul Coresi, p. 39. The older opinions about Coresi's Greek origin or about his paternal kinship with the Bulgarian priests of Şcheii Braşovului, the latter opinion being quite isolated, have been rejected in several studies, starting with N. Iorga, and finally his Romanian origin came to be supported (Lajos - Lidia Demény, Carte, tipar și societate, p. 328; Gheţie - Mareş, Diaconul Coresi, pp. 16, 18, 32-35; about the analysis of Coresi's origin see also Urs, Diaconul Coresi, pp. 25-43).

${ }^{9}$ Urs, Diaconul Coresi, p. 39.

${ }^{10}$ Gheție - Mareş, Diaconul Coresi, p. 36; Urs, Diaconul Coresi, pp. 40, 289-290; Traian Vedinaș, Coresi, București, 1985, p. 19 (hereinafter: Vedinaș, Coresi).

${ }^{11}$ According to some researchers and biographers, the term deacon indicated during that epoch not just the first level in the hierarchy of Priesthood, but also a lay position, because a series of terms, like grămătic, diac, diacon, piseț, logofăt, designated "the minor writer of Slavonic language in a chancery" (Vedinaș, Coresi, pp. 13-14). However, in the case of Coresi it has been affirmed that he was part of the hierarchy of the Orthodox Church as a deacon (Gheție - Mareş, Diaconul Coresi, p. 36; Urs, Diaconul Coresi, p. 38), being the only $16^{\text {th }}$ century printer to bear this title [Gheţie - Mareş, Diaconul Coresi, p. 263; see also Al. Mareş, "În legătură cu activitatea tipografică a diacului Lorinț", in Limba română 19/2 (1970), p. 130 (hereinafter: Mareș, Diacul Lorint) ], and also that he remained until the end of his earthly life on this level because he was never forgiven, according to the opinion of some researchers, the act of putting the Lord's word into Romanian [B. Theodorescu, "Personalitatea diaconului Coresi și rolul lui în cultura românească", in Biserica Ortodoxă Română 77/3-4 (1959), p. 298].

${ }^{12}$ Păcurariu, Istoria Bisericii, I, pp. 471, 477; Lajos - Lidia Demény, Carte, tipar și societate, p. 328. For the fact that he appears on the second position in the Epilogue of the respective Oktoikh, some researchers consider that deacon Coresi learnt the art of the printing press from Oprea himself, also known under the appellative of Oprea the Logothete (Vedinaș, Coresi, p. 15). The Oktoikh was printed using letters that had belonged to the printing press of Dimitrie Liubavici (Gheție - Mareş, Diaconul Coresi, p. 37).

${ }^{13}$ Gheţie - Mareş, Diaconul Coresi, p. 155. 
representing the first edition of this liturgical book made in Wallachia, was finished in 1558 and took place in Târgoviște ${ }^{14}$, where, after the impression of the respective book, the printing activity will be interrupted for about 90 years ${ }^{15}$.

Deacon Coresi will continue his printing activity in Brașov, in Transylvania, where he will settle himself for good, according to the unanimous opinion of the researchers, in $1559^{16}$, in the context of the ceasing of the printing activity using Cyrillic letters of Sibiu and of the resuming of the activity of the printing press from Brasov, which was the main consumer of the paper production manufactured by the local mill, but also in the context of the intensification of the protestant propaganda among the Romanians ${ }^{17}$. It should be mentioned that in Transylvania the printing activity had begun even since the first part of the $16^{\text {th }}$ century, at first in Sibiu ${ }^{18}$, from where it was spread to other centres as well ${ }^{19}$, bearing, however, the mark of the protestant propaganda, first Lutheran and then Calvinist.

According to the testimonies gathered by the researchers from the Epilogues of the books printed by deacon Coresi, submitted to certain analyses for the cases when the indication of the printing place is missing, it results that he undertook his activity in the printing centres of Brașov (during two periods: 1556-1557; 1560-1583, with certain interruptions), Târgoviște (1557-1558), Alba Iulia (1567-1568) and Sas-Sebeș (1580), along five great periods $(1556-1558,1559-1565,1566-1570,1571-1577,1578-1583)^{20}$, his printing activity being based on orders arrived from Transylvania and Wallachia ${ }^{21}$. In order to

${ }^{14}$ Begun on 8 July 1557, the respective work was finished on 30 July 1558, during the third reign (1558-1559) of Mircea the Shepherd, for which reason he is also put down as editor, along with Pătraşcu the Good, in the Epilogue of this book (Păcurariu, Istoria Bisericii, I, pp. 472, 477-478; Gheţie - Mareş, Diaconul Coresi, pp. 154-155; Urs, Diaconul Coresi, p. 225).

15 Păcurariu, Istoria Bisericii, I, pp. 472, 478. It should be mentioned that the printing activity will not cease for good in Wallchia, in the $16^{\text {th }}$ century, because a printing press is mentioned near Bucharest, at the monstery of the Holy Prophet John the Baptist, known, since the $17^{\text {th }}$ century, under the name of Plumbuita. In this printing center will operate the hieromonk Lavrentie and his disciple Iovan (Ioan or John), considered of Romanian origin and who will print books in Slavonic, see Păcurariu, Istoria Bisericii, I, p. 472; see also Lajos - Lidia Demény, Carte, tipar și societate, pp. 106-127; Urs, Diaconul Coresi, pp. 73-77. After a standstill of several decennia (1582-1635), the printing activity is resumed in Wallachia, during the reign of Prince Matei (Matthew) Basarab, in several printing centers, among them being Dealu Monastery (1642-1649), nearby Târgoviște, and even Târgoviște (1649-1652), see Ion I. Croitoru, op. cit., I, p. 251.

${ }^{16}$ Lajos - Lidia Demény, Carte, tipar și societate, pp. 89, 328; Păcurariu, Istoria Bisericii, I, p. 478; Gheţie Mareş, Diaconul Coresi, p. 38; Urs, Diaconul Coresi, p. 40; Vedinaş, Coresi, p. 15.The place where the books were printed indicates the fact that after he settled himself in Braşov, where he is considered to have had his permanent domicile, Coresi no longer returned to Târgoviște, carrying out his activity in Brașov and in other localities nearby, according to the orders received (Urs, Diaconul Coresi, p. 40).

${ }^{17}$ Gheție - Mareş, Diaconul Coresi, p. 38; Urs, Diaconul Coresi, pp. 98-103; see also Al. Mareș, "Note despre Coresi”, in Limba română 19/3 (1970), pp. 254-257.

${ }^{18}$ In 1528 or even before that, a printing press had been created in Sibiu for the Saxons' needs, later on endowed as well with a section of Cyrillic, where Filip the Moldavian will work [Păcurariu, Istoria Bisericii, I, p. 474; Mircea Tomescu, Istoria cărţii româneşti de la începuturi până la 1918, București, 1968, pp. 36-37, 45 (hereinafter: Tomescu, Istoria cărții); I. Crăciun, Catechismul românesc din 1544 urmat de celelalte catechisme româno-luterane Bârseanu, Sturdzan şi Marţian, Sibiu/Cluj, 1945-1946, pp. 23-24 (hereinafter: Crăciun, Catechismul românesc din 1544)].

${ }^{19}$ Actually, the printing of books in these printing centers of Transylvania, in Romanian and Slavonic, some of them used as well by the protestant propaganda, will be related to the activity of deacon Coresi and his son, Şerban, and to the activity of the disciples they train, in Braşov, Alba Iulia, Sas-Sebeş and Orăştie, during the second half of the $16^{\text {th }}$ century, see Tomescu, Istoria cărţii, pp. 46-54; Păcurariu, Istoria Bisericii, I, pp. 474486.

${ }^{20}$ Gheţie - Mareş, Diaconul Coresi, p. 37.

${ }^{21}$ Gheţie - Mareş, Diaconul Coresi, p. 36; Urs, Diaconul Coresi, p. 102. 
highlight some features of the printing activity undertaken by deacon Coresi in Transylvania, it has been affirmed that, after he settled himself in Brașov, he created a new type of letter, which means that he did not bring along with him the printing press from Târgoviște, but probably he exchanged printing material, during certain periods, with other printing masters of his time ${ }^{22}$, and that his activity, at least during the periods $1559-1565,1566-1570$, was not due to some local Orthodox or Wallachian initiative, but to the reformed patronage of Brașov, a case similar to the activity of the first printing press of Romanian book from Sibiu. Yet, after the year 1571, when, in the place of John II Sigismund Zápolya (1540-1551, 1556-1571), the Roman-Catholic Stephen III Báthory (1571-1583) ${ }^{23}$ becomes head of Transylvania, the protestant propaganda recoils, this being a period during which deacon Coresi prints Slavonic but also Romanian books, with no major protestant influences in their content ${ }^{24}$. Consequently, Coresi's activity also represented a means for the realization of the objectives of the religious and denominational policy pursued by the authorities of Transylvania, so that the respective activity is the result of a complex situation to which will contribute factors of religious, cultural, political and, last but not least, economic nature ${ }^{25}$.

In relation to the activity of deacon Coresi, who is supposed to have honoured the grace of the priestly ministry at the church of Șcheii Brașovului ${ }^{26}$, it has also been stated that he was not just a printer but also a corrector of the texts that were entrusted to him for printing, yet to a lesser extent or not at all their translator into Romanian ${ }^{27}$. On the one hand, this observation does not diminish Coresi's merits too much ${ }^{28}$, because the fact of printing Romanian books, in those times, was a merit at least just as great as that of having translated them $^{29}$. On the other hand, this thing means that the phenomenon of the translation of the Orthodox Church books into Romanian is not exclusively the result of the reform spirit initiated by the protestants, but is much older, comprising areas such as Maramures, Moldavia and Muntenia, the last represented especially by Coresi, to which BanatHunedoara and the Transylvania situated north of Mureș will be added ${ }^{30}$, since a part of the versions printed were put together especially to be printed by Coresi, whereas others had circulated in copies for quite a while previously ${ }^{31}$, because even before the installation of the

\footnotetext{
${ }^{22}$ See Urs, Diaconul Coresi, pp. 108-117.

${ }^{23}$ It ought to be mentioned that the Báthory family, becoming leaders of Transylvania for about three decennia, towards the end of the $16^{\text {th }}$ century, favoured the restrenghtening of the Roman-Catholicism, under the action of the Counter-Reformation and with the help of the Jesuits [Ion I. Croitoru, "Biserica Ortodoxă din Țările Române ca front de rezistenţă în faţa prozelitismului protestant din secolul al XVII-lea. 4.1. Propaganda protestantă în Țările Române" (hereinafter: Croitoru, Propaganda protestantă), in idem, Ortodoxia și Apusul în tradiția spirituală a românilor. Unitatea Ortodoxiei și apărarea credinței ortodoxe în fața propagandei protestante din secolul al XVII-lea, vol. II, Târgoviște, 2012 (hereinafter: Croitoru, Ortodoxia și Apusul, II), p. 473].

${ }^{24}$ Urs, Diaconul Coresi, pp. 99-101; Al. Mareș, "Note despre...”, pp. 255-257; Ion Gheție, “Coresi și Reforma în lumina unor interpretări noi”, in Studii și cercetări lingvistice 18/2 (1967), p. 238.

${ }^{25}$ Urs, Diaconul Coresi, p. 102.

${ }^{26}$ Antonie Plămădeală, Dascăli de cuget și simţire românească, București, 1981, p. 76, note 44 (hereinafter: Plămădeală, Dascăli).

${ }^{27}$ Gheţie - Mareş, Diaconul Coresi, pp. 36, 47, 211-220, 265, 379; Urs, Diaconul Coresi, pp. 127, 291.

${ }^{28}$ Gheţie - Mareş, Diaconul Coresi, p. 378.

${ }^{29}$ Sextil Puşcariu, Istoria literaturii române. Epoca veche, edition arranged by Magdalena Vulpe, postface by Dan C. Mihăilescu, București, 1987, p. 63. In this sense, the researchers have noticed that when deacon Coresi speaks about the actions of translating and printing, he makes a clear distinction between them, because by the term writing (a scrie) he understood printing, while the term releasing (a scoate) meant for him translating, not printing (Urs, Diaconul Coresi, p. 125).

${ }^{30}$ Gheţie - Mareş, Diaconul Coresi, pp. 265, 376-378; Urs, Diaconul Coresi, p. 127-130.

${ }^{31}$ Urs, Diaconul Coresi, p. 130.
} 


\section{Slavonic language with us, the Scripture was known, read, translated, explained in} Romanian out loud and in writing ${ }^{32}$.

To support his printing activity, deacon Coresi got help from a variable number of master printers (for some printings five, for others eight or ten aides), out of whom some were trained by him (the clerks Călin ${ }^{33}$, Tudor, Mihăilă, Marien, Lorinț ${ }^{34}$, to which one can add his son Serban $\left.{ }^{35}\right)^{36}$. Next to the above-mentioned aspects, one can also add the fact that deacon Coresi was the editor of some books in Slavonic ${ }^{37}$, out of economic but also denominational reasons (the ones in Slavonic were circulating in a larger area and this could assure a better selling of the books; the printings in Romanian were received with reticence) ${ }^{38}$.

According to the latest research works, the synoptic image of the books printed by deacon Coresi looks as follows: 10 books into Romanian, out of which the Psalter in two editions [namely Întrebare creștinească (Christian Question) or Catehism (Catechism, Brașov, 1560); Tetraevanghel (Tetraevangelion, Brașov, 1561); Pravila Sfinților Apostoli or a Sfinților Părinți (Pravila or the Nomocanon of the Holy Apostles or of the Holy Fathers, Brașov, 1560-1562); Lucrul apostolesc (The Apostolic Work) or Apostol (Apostolos), also called Praxiu (Praxis, Brașov, 1566); Tâlcul Evangheliilor (The Interpretation of the Gospels) or Cazania I (Kazania or Homiliary I, Alba Iulia, 1567-1568); Molitvenic (Euchologion or Trebnik), called Molitevnic rumânesc (Romanian Euchologion, Alba Iulia, 1567-1568) ${ }^{39}$; Psaltire (Psalter, Brașov, 1568) ${ }^{40}$; Psaltire (Psalter, Brașov, 1570); Liturghier (Hieratikon or Sluzhebnik, Brașov, 1570); Evanghelia învățătoare (The Teaching or Didactic Gospel), Evanghelia cu învățătură (The Gospel with teaching) or Cazania II (Kazania or Homiliary II, Brașov, 1581)]; 14 books into Slavonic, out of which the Psaltir in four

32 Plămădeală, Dascăli, p. 67. As far as the use of the Slavonic language by the Romanian people is concerned, only Slavic-Romanian dictionaries are known and not even one of Romanian-Slavic, to teach the Slavonic to the Romanians, which denotes that this need was not felt (Plămădeală, Dascăli, pp. 68-69).

${ }^{33}$ About the printing activity of clerk Călin see Urs, Diaconul Coresi, pp. 83-85.

${ }^{34}$ One can note that during the same period as deacon Coresi, clerk Lorint undertook his printing activity as well. Of Saxon origin, clerk Lorinț lived in Brașov, yet he was also active in Alba Iulia, printing books in Slavonic, out of financial reasons. Known under the Latinized name Laurentius Fronius, but also under the name Laurentius Schreiber, Lorint is said to have learnt the art of the printing press in deacon Coresi's workshop, with whom he had moments of professional collaboration, but also of competition, an action in court (1570) being also recorded between them. Clerk Lorint is the first printer to have obtained a privilege for the printing of a book for a 30-year period, granted by Christopher Báthory in the case of the Slavonic Chetveroevangelie, printed in Alba Iuia, in 1579 (Urs, Diaconul Coresi, pp. 77-83; Păcurariu, Istoria Bisericii, I, p. 484; see also Mareș, Diacul Lorinț, pp. 129-137).

35 About the printing activity of Șerban Coresi, which concludes the series of the $16^{\text {th }}$ century Romanian printings, see Urs, Diaconul Coresi, pp. 85-87.

${ }^{36}$ Gheţie - Mareş, Diaconul Coresi, p. 48; Urs, Diaconul Coresi, pp. 39-40, 290.

${ }^{37}$ For instance, for the books: Slavonic Sluzhebnik (Brașov, 1568), Slavonic Psaltir (Brașov, 1568-1570; 1576), Slavonic Sbornik (vol. I-II, Brașov, 1569) and Slavonic Chetveroevangelie (Brașov, 1579), for the last one being co-editor along with Mănăilă (Gheţie - Mareş, Diaconul Coresi, pp. 42, 167-168, 180, 185, 191, 202).

${ }^{38}$ Urs, Diaconul Coresi, p. 124.

39 The two books, The Interpretation of the Gospels and the Euchologion, were printed in one volume, according to some, in Brașov, Sibiu or Sas-Sebeș, according to others, in Teiuș, Alba Iulia, Aiud, Cluj or Abrud (Gheție - Mareş, Diaconul Coresi, pp. 104, 118), but it seems that in the specialized literature the locality standing out among all these as the most likely printing location is Alba Iulia (Urs, Diaconul Coresi, pp. 174-175).

${ }^{40}$ About this edition, some researchers claim it was bilingual, in the languages Slavonic and Romanian (Gheţie - Mareş, Diaconul Coresi, p. 124). Therefore, this issue remains open to some future studies, see Urs, Diaconul Coresi, pp. 188-189. 
editions, the Great Oktoikh in two volumes, but in different years, the Postnaya Triod in two editions $^{41}$, the Chetveroevangelie in three editions and the Sbornik in two editions ${ }^{42}$ [Small Oktoikh (Brașov, 1557); Postnaya Triod-Tsvetnaya Triod (Triodion-Pentecostarion, Târgoviște, 1558); Chetveroevangelie (Brașov, 1562); Sluzhebnik (Brașov, 1568); Slavonic Sbornik, also called Prazdnicnaya Mineya or Festal Menaeon (vol. I-II, Brașov, 1569); Psaltir (Brașov, 1568-1570); Psaltir (Brașov, 1572-1573); Oktoikh or Great Oktoikh (vol. I, Brașov, 1574); Oktoikh or Great Oktoikh (vol. II, Brașov, 1575); Psaltir (Brașov, 1576); Psaltir (Brașov, 1577); Postnaya Triod, also called Lenten Triodion (Brașov, 1578); Chetveroevangelie (Brașov, 1579); Sbornik (Sas-Sebeș, 1580); Chetveroevangelie (Brașov, 1583)]; and a bilingual book, namely Slavic-Romanian [Psaltir / Psaltire (Brașov, 1577)] ${ }^{43}$.

The exact date of Coresi's birth is not known, different options being recorded (1507, 1510,1532 etc.), yet the date of his passage in the life beyond grave is not known either, being admitted that this event occurred after the year 1583, when the last book printed by Coresi, together with Mănăilă (Slavonic Chetveroevangelie, Brașov) is recorded, more precisely, after the month of July of the year 1583, when on the throne of Wallachia comes Prince Peter Earring (1583-1585), the one who funded the publication of the respective book $^{44}$.

\section{THE REFORMATION IN TRANSYLVANIA AND THE STATUS OF CHRISTIAN DENOMINATIONS}

The ideas of the Reformation, under the form of Lutheranism, penetrated first of all among the Saxons of Transylvania, either due to the commercial exchanges they had with great centers of Central and Western Europe, or due to the intellectual and cultural relations they had with cities and university centres of Germany. Consequently, the cities they resided in, like Brașov, Sibiu and Sighișoara, get to become the main centers from which Lutheranism will spread out, gaining followers among the Hungarians as well, acquiring the status of received religion (religio recepta) or denomination in Transylvania (The Diets of Turda of the years 1550 and 1557) ${ }^{45}$. The main propagator of the Lutheran doctrine was Johannes Honterus (1498-1549), who edited Martin Luther's works (1438-1546) in the printing press created by him in Brașov (1533), and a few works of his own, considered normative for the organization of the Saxons' Lutheran $\mathrm{Church}^{46}$. Although Philipp Melanchthon (1497-1560) had received with satisfaction, in 1539, the news that the Reformation was beginning to gain ground among the Romanians, as well, he had discussions, in 1544, with Honterus precisely about the difficulties encountered by the dissemination of the Reformation among the latter ${ }^{47}$. Actually, during the same year, it will be decided in Sibiu that all those who have not received God's word under its new form

\footnotetext{
${ }^{41}$ The first edition together with the Tsvetnaya Triod, and the second separately.

42 The first edition is in two parts.

43 Gheţie - Mareş, Diaconul Coresi, pp. 55-210; Urs, Diaconul Coresi, pp. 140-274, see also Otilia Urs, "Istoriografia coresiană. Partea I. Bibliografia tipăriturilor coresiene", in Transilvania 4 (2012), pp. 57-61.

${ }^{44}$ Urs, Diaconul Coresi, pp. 35, 41; see also Al. Mareș, “Când a murit Coresi?”, in Limba română 21/2 (1972), pp. 155-158; for a bibliography regarding the life and the activity of deacon Coresi, see Otilia Urs, "Istoriografia coresiană. Partea a II-a. Bibliografia vieții și a activității diaconului Coresi”, in Transilvania 8 (2012), pp. 50-55.

${ }^{45}$ See Croitoru, Propaganda protestantă, pp. 470-471.

${ }^{46}$ See Croitoru, Propaganda protestantă, p. 470, note 19.

47 Şerban Papacostea, "Moldova în Epoca Reformei. Contribuţie la istoria societăţii moldoveneşti în veacul al XVI-lea”, in Studii. Revistă de istorie 11/4 (1958), p. 60; George Ivaşcu, Istoria literaturii române, I, Bucureşti, 1969, p. 101 (hereinafter: Ivaşcu, Istoria); Croitoru, Propaganda protestantă, p. 470, note 17.
} 
should be exhorted in a brotherly manner to adopt it, and the youth should be stimulated to read the catechism ${ }^{48}$.

At the same time, the Calvinism also penetrated in Transylvania, spread especially among the Hungarians and the Szeklers, having the city of Cluj as its center, and as a famous representative the Saxon Gáspár Heltai (c. 1510-1575). After disputes with the Lutherans (1550-1564), the Calvinism acquires as well the status of received religion in Transylvania (according to some, in the Diet of Aiud of the year $1564^{49}$, and according to others in the Diet of Turda of the year 1568), so that the ethnic-religious and denominational array of Transylvania gets to become the following (the Diet of Turda of the year 1568): the Saxons declare themselves Lutherans; the Hungarians and a part of the Szeklers admit they are Calvins; a part of the Hungarians declare themselves Unitarians; the Romanians, representing the majority of the population, remain Orthodox ${ }^{50}$. As a result, four received religions or Christian denominations are acknowledged in Transylvania (the Diet of Turda of the year 1568), Lutheran or Augustan, Reformed or Calvinist, Unitarian or Antitrinitarian and Roman-Catholic, the last being put on the offensive by the three protestant denominations acknowledged officially, yet it will consolidate its status towards the end of the $16^{\text {th }}$ century ${ }^{51}$.

The Orthodox Church of the Romanians of Transylvania was not acknowledged among the received religions or denominations, but was awarded the status of tolerated religion (religio tolerata, the Diet of Turda of the year 1566), so that the Romanians did not appear among the nations of the Principality. On the contrary, they will see themselves limited in their ecclesial life by a new propaganda, first Lutheran, then Calvinist, which will replace the former Roman-Catholic action of proselytism ${ }^{52}$. In spite of the pressures and, evidently, of the expectations from the representatives of the protestant propaganda, one can note that the Romanians maintain their firm loyalty to their ancestral faith, namely the Orthodox one, and this attitude of theirs was consequently due to the fact that they had not experienced, regarding their ecclesial and spiritual life, any crisis similar to the one lived by the Roman-Catholic Hungarians, Saxons and Szeklers who embraced the Reformation and, in this way, facilitated its penetration in the Principality of Transylvania ${ }^{53}$.

\section{THE PROTESTANT (LUTHERAN, CALVINIST) PROPAGANDA USING THE PRINTING PRESS IN ROMANIAN. THE EDITORIAL PLAN OF DEACON CORESI}

One can note that, towards the middle of the $16^{\text {th }}$ century, there appears, in the protestant academic environment (Wittenberg, Tübingen, Geneva etc.), the initiative to attract the Orthodox as a whole towards embracing the Reformation, which determined the attitude of

\footnotetext{
${ }^{48}$ Crăciun, Catechismul românesc din 1544, p. 16. Introducere)].

${ }^{50}$ Croitoru, Propaganda protestantă, p. 471; Urs, Diaconul Coresi, p. 193.

${ }^{51}$ Croitoru, Propaganda protestantă, p. 473.

${ }^{52}$ Croitoru, Propaganda protestantă, pp. 473-474.

${ }^{53}$ Croitoru, Propaganda protestantă, p. 471.
}

49 This Diet officially consecrates the division of the Protestant Church of Transylvania into two denominations: the Calvinist one, embraced by the Hungarians, of whom a part will pass to the Unitarianism (1568), and the Lutheran denomination, supported by the Saxons [Al. Mareş, "Introducere", in Liturghierul lui Coresi, text established, introductory study and index by Al. Mareş, Bucureşti, 1969, p. 7 (hereinafter: Mareș, 
propaganda of the Lutherans and of the Calvinists in the Orthodox world of Greek, Slavic and Romanian language ${ }^{54}$.

Therefore, the Lutherans of Transylvania or Ardeal began their propaganda at the exhortation and with the support of the center of Wittenberg ${ }^{55}$, using the printing press in Romanian $^{56}$. Thus, they print in Sibiu ${ }^{57}$, in 1544, a Catechism ${ }^{58}$, realized with the participation of the master printer Filip the Moldavian, alias Philippus Pictor or Maler / Mahler ${ }^{59}$. This Catechism, representing the first book of the Romanian area printed in

${ }^{54}$ Maria Crăciun, Protestantism şi Ortodoxie în Moldova secolului al XVI-lea, Cluj-Napoca, 1996, pp. 31-34 (hereinafter: Crăciun, Protestantism şi Ortodoxie); Croitoru, Propaganda protestantă, p. 471, note 31; Urs, Diaconul Coresi, p. 70.

55 Virgil Molin, «În legătură cu circulaţia unui „,catehism vechi” din veacul XVI», in Biserica Ortodoxă Română 77/3-4 (1960), p. 367 (hereinafter: Molin, Circulaţia unui „,catehism vechi”). Melanchthon was a preacher directly responsible for organizational issues in Transylvania (Molin, Circulaţia unui „,catehism vechi”, p. 368).

56 The use of the printing press in the framework of the Lutheran propaganda is also accompanied by administrative measures, like those of the year 1559, taken by the City Council of Braşov to impose the Lutheran Catechism to the Romanians of Şcheii Braşovului, while a preacher will vow, in the year 1565, to convert the Romanians to Lutheranism (Crăciun, Protestantism şi Ortodoxie, p. 39).

${ }^{57}$ It has been affirmed that the Lutheran propaganda had become more insistent in Sibiu, by the election in 1543 of Petrus Haller as judge (judex civitatis) of the city (Tomescu, Istoria cărţii, p. 45). Actually, the Saxon University of Sibiu decided, in the same year, that all the inhabitants of Transylvania should receive the new faith, namely the Lutheranism, regardless of their social situation and national belonging, a decision decreed as well in the year 1544, when a Greek Catechism appears in Brașov as well, with the same intentions of propaganda (Urs, Diaconul Coresi, pp. 62-63, 90-91). Regarding the printing date of this Greek Catechism, the year 1546 has been proposed as well, the same book being reprinted in 1550, in the same locality [Crăciun, Catechismul românesc din 1544, pp. 16-17, note 62; Ioan Lupaş, Istoria bisericească a românilor ardeleni, ClujNapoca, ${ }^{2} 1995$, p. 52 (hereinafter: Lupaş, Istoria bisericească); Molin, Circulaţia unui „,catehism vechi”, p. 368]. Regarding the activity of the Cyrillic printing press undertaken in Wallachia, it has been considered that the printing press of Sibiu appears after that of Macarie from Dealu Monastery (1508-1512) and simultaneously to that of Dimitrie Liubavici of Târgoviște (1544-1559), see Lajos - Lidia Demény, Carte, tipar și societate, p. 59; Urs, Diaconul Coresi, p. 67.

${ }^{58}$ In relation to this Catechism, which has not been preserved, it is supposed to have been a compilation after several sources, some of them Orthodox, adapted to the Lutheran requirements (Crăciun, Catechismul românesc din 1544, pp. 11-12). For a reconstitution of this text, see Crăciun, Catechismul românesc din 1544, pp. 31-38.

59 The series of printings realized by this master printer of Moldavia continues in Sibiu, with two more books for the needs of the Orthodox cult: Slavonic Chetveroevangelie (1546), for which the model used was the edition of Macarie from Wallchia (1512), yet destined now, however, not just for the Orthodox Church of Transylvania, but also for the worship needs of the Orthodox Church of Moldavia, because this book, representing, with the Romanians, the first printing embellished with engravings, also bore the coat of arms of the respective country; Slavic-Romanian Chetveroevangelie or Evangelie (Tetraevanghel or Evangheliar slavoromân, 1551-1553), being the first printing in Romanian preserved in part and whose publication was due, according to some, to the Lutheran propaganda, since the Romanian text aimed to compromise the Orthodox hierarchy and clergy in front of the Romanian believers, calling the high priest or the archiereus who sentenced Jesus Christ to death, metropolitan, Caiaphas and the high priests of the old Law, bishops, and, in another place, the Pharisee, confessor or spiritual father (Tomescu, Istoria cărţii, pp. 36-37; Păcurariu, Istoria Bisericii, I, pp. 475-477; Ivaşcu, Istoria, p. 98; Lajos - Lidia Demény, Carte, tipar și societate, pp. 59, 61, 69-82, 325326; Urs, Diaconul Coresi, pp. 63-66). Others consider that the text was translated from Slavonic and brought from Moldavia simply with an inadequate translation of the term $\dot{\alpha} \rho \chi \imath \rho \varepsilon \varepsilon \dot{s} \varsigma$, printed probably at the request of the Moldavian reigning Prince Ştefan Rareş (Păcurariu, Istoria Bisericii, I, pp. 477). Considering the Romanian translations of the Holy Scripture of the $15^{\text {th }}-16^{\text {th }}$ century, we believe that the mistaken translation is attributable to the Lutheran propaganda (Croitoru, Propaganda protestantă, p. 474, note 49; see also Urs, Diaconul Coresi, pp. 65-66). Actually, even the Slavonic Chetveroevangelie of 1546 did not escape the Lutheran influence either, because from the content of the Preface to the Gospel according to Matthew was 
Romanian $^{60}$, triggered protests from the Romanian Orthodox priests, given its contents, or admiration only for the fact that it had been printed in Romanian ${ }^{61}$. Leaving aside the content of reformed orientation ${ }^{62}$, the Romanian cultural environments became aware, by the respective Catechism, of the possibility of using the Romanian language in the cult of the Orthodox Church, but also as a language of culture. From this perspective, the Catechism was of some interest, which explains, for instance, the fact that the Wallachian reigning Prince Pătrașcu the Good is brought from Sibiu, in 1556, as a consequence of his request, a copy of this book, by means of the magistrate of Braşov ${ }^{63}$. The second printing press that the Lutherans benefited of was the one in Braşov. The activity of this printing press, founded in $1533^{64}$ by Johannes Honterus ${ }^{65}$, was also facilitated by the existence of the first paper mill of Transylvania (1546) in the same locality, whose owners were the judges of the city, Hans Benkner $(\dagger 1565)$ and Hans Fuchs ${ }^{66}$. At this printing press, it was under the patronage of the Lutherans that the printing of books in Romanian and Slavonic took place, combining, on the one hand, the Protestant propaganda with the economic interests of the printing press and paper mill owners, who realize that a propaganda waged among the Romanians is useless and with no result, and, for this reason, view the printing of books rather as a trade meant to bring profit ${ }^{67}$. On the other hand, they had in view the requirements and cult needs in

eliminated the fragment regarding the need to maintain the Orthodox faith intact, and regarding the fight against heresies, present in all the Orthodox Tetraevangelia, among them being also the one printed by Macarie at Dealu Monastery near Târgoviște, in 1512 (Urs, Diaconul Coresi, pp. 64-65). About other possible printings made by Filip the Moldavian see Urs, Diaconul Coresi, p. 61; Ion Gheție, "Un Apostol românesc tipărit la Sibiu de Filip Moldoveanul?”, in Studii și cercetări de lingvistică 22/5 (1971), pp. 515-518.

${ }^{60}$ Tomescu, Istoria cărţii, p. 45; Ivaşcu, Istoria, p. 98.

${ }^{61}$ A testimony in this sense is the affirmation of the Saxon pastor Adalbert Wurmloch, who was writing to Johann Hess of Breslau, in 1564, that the Catechism has been translated into Romanian (in linquam wallachicum) and has been printed in Sibiu... with characters called Serbian, which somehow remind of the shape of the Greek letters. And many of the priests treasure this booklet as something holy, others simply disdain it [Eudoxiu de Hurmuzaki, Documente privitoare la Istoria Românilor, vol. XI (1517-1612), Documents collected, annotated and published by Neculaĭ Iorga, Bucuresci, 1900, p. 859 (hereinafter: Hurmuzaki, XI); BRV, I, p. 22; see also Crăciun, Catechismul românesc din 1544, pp. 2, 15, 16; C. C. Giurescu, Transylvania in the History of Romania, An Historical Outline, London, 1972, p. 104; Lupaş, Istoria bisericească, p. 52, note 11; Urs, Diaconul Coresi, pp. 61-62, 278].

${ }^{62}$ Urs, Diaconul Coresi, pp. 62, 66-67. Most of the researchers consider that this Catechism comprised Lutheran teachings, being based on Luther's Small Catechism. Other historians, however, consider it alien to all Lutheran influence, while in their opinion its rejection was due only to the deep-rooted tradition of using the Slavonic language in the cult and to the reluctance to accepting the change of the liturgical language, because it was coming as a measure imposed by the heretics [Păcurariu, Istoria Bisericii, I, pp. 475, 487 (bibliography)].

${ }^{63}$ Urs, Diaconul Coresi, pp. 62, 146; see also Arnold Huttmann, Pavel Binder, "Contribuții la biografia lui Filip Moldoveanul, primul tipograf român”, in Limbă şi literatură 16 (1968), p. 165.

${ }^{64}$ Concerning the foundation data of the respective printing press, among the years proposed, there are also 1535 or 1539 . The number of books printed between the years $1535-1537$ is 53, out of which 33 in Latin (C. Durandin, Histoire des roumains, Paris, 1995, p. 77; Urs, Diaconul Coresi, p. 91).

${ }^{65}$ About Honterus, a reformer of Brașov and of Țara Bârsei, appointed senior pastor of the Lutheran Church of Braşov, in 1544, see Gernot Nussbächer, Johannes Honterus, București, 1977; Ludwig Binder, "Contribuția lui Johannes Honterus la Reforma din Transilvania”, in Mitropolia Ardealului 24/4-6 (1979), pp. 353-363.

66 "Personalitatea Diaconului Coresi şi rolul lui în cultura românească”, in Biserica Ortodoxă Română 77/3-4 (1959), p. 294; Urs, Diaconul Coresi, p. 93; about Johannes or Hans Benkner, see Gernot Nussbächer, Johannes Benkner, Sein Leben und Wirken in Wort und Bild, București, 1983.

${ }^{67}$ Ştefan Meteş, Istoria Bisericii şi a vieţii religioase a românilor din Transilvania şi Ungaria, I (până la 1698), Sibiu, ${ }^{2} 1935$, pp. 79-80 (hereinafter: Meteș, Istoria Bisericii); Etienne Meteş, La vie menée par les Roumains en Transylvanie du XVI ${ }^{-e}$ au XVIII ${ }^{-e}$ siècle, Bucarest, 1938, pp. 16-17; Virgil Molin, "Coresi editor şi tipograf", in Biserica Ortodoxă Română 77/3-4 (1959), pp. 310, 312, 315. 
Slavonic of the Orthodox Church of the three Romanian Countries ${ }^{68}$. This explains the appearance of the Wallachian coat of arms in the books printed in Braşov, and the mention in them of certain Romanian reigning princes and metropolitans ${ }^{69}$. All these were done out of several reasons, meant to assure to the books, by the mention of the Reign and of the right-glorifying Church of the Romanian extra-Carpathian Countries, the authority necessary to their circulation not just in the areas inhabited by the Orthodox Romanians but also in those parts of the Orthodox world that were of Slavonic language ${ }^{70}$.

In this context of denominational policy and propaganda, the printing of the books meant for the Orthodox Church is also related to the activity of deacon Coresi. He will collaborate with the judges of Braşov, the Lutherans Johannes or Hans Benkner and Lukas Hirscher, and then with the Hungarian nobleman Miklós Forró Háportoni or of Háporton (Hopârta), one of the propagators of Calvinism in Transylvania, and will have the assistance and the aid of the Romanian Orthodox priests (Toma, Iane and Mihai) of Saint Nicholas Church of Şcheii Braşovului ${ }^{71}$. Around this church, helped with numerous donations by the reigning princes of Wallachia, a cultural resistance core of the Romanians had taken shape, where priest Mihai will edify, in 1597, a Romanian school ${ }^{72}$. According to some more recent research works, was accredited the idea according to which deacon Coresi used, in order to print these books, not Honterus' Lutheran printing press, which was then taken over by Valentin Wagner, but a printing workshop of his own, settled next to Saint Nicholas Church of Şcheii Braşovului ${ }^{73}$, whose priests would have brought Coresi from Târgoviște to Brașov $^{74}$. However, some researchers, on the one hand, deny Coresi's independent activity as a typographer, this issue remaining, therefore, open to future studies, and, on the other hand, affirm that the place of the printing press where Coresi worked was not in Şcheii Braşovului, which was one of the three suburbs of the city Braşov (Şcheii, Bartolomeu and Blumăna), but in Braşov, without denying his collaboration with the priest of Saint Nicholas Church $^{75}$.

${ }^{68}$ Croitoru, Propaganda protestantă, p. 475.

${ }^{69}$ For instance, in the Epilogue included in the Slavonic Oktoikh, a book necessary in the Orthodox cult and the first of this kind printed in Braşov by Oprea the Logothete and deacon Coresi, between 12 June 1556 and 14 January 1557, at the order of Hans Benkner, were reminded the Ruler of Wallachia and that of Moldavia, Pătrașcu the Good and Alexander Lăpuşneanu, along with the Prince of Transylvania, John II Sigismund Zápolya, and his mother, Isabella. The conclusion is that the editor had not proceeded at the printing of this book, whose content was rejected by the Lutheran doctrine, out of love for the divine and holy churches, as it was written in the Afterword, but rather out of material interests (Păcurariu, Istoria Bisericii, I, p. 477; Gheţie Mareş, Diaconul Coresi, pp. 145-146).

${ }^{70}$ Croitoru, Propaganda protestantă, p. 475.

${ }^{71}$ Urs, Diaconul Coresi, p. 94; Candid C. Mușlea, Biserica Sfântul Nicolae din Șcheii Brașovului, I, Brașov, 1937, p. 251.

72 Păcurariu, Istoria Bisericii, I, pp. 483, 486. The school of Șcheii Brașovului is confirmed in documents for the first time in the year 1399, and then in 1495 or, according to some researchers, in 1512 or 1515 , when the reigning Prince of Wallachia Neagoe Basarab contributes to the extension of this school and of the church (Urs, Diaconul Coresi, p. 94; Candid C. Mușlea, op. cit, p. 85; Gernot Nussbächer, Din cronici și hrisoave. Contribuții la istoria Transilvaniei, București, 1987, p. 135). Coresi's printings were used as manuals at the respective school, as he himself mentions in the Epilogue of the edition of the year 1577 of the Slavic-Romanian Psaltir (BRV, I, p. 64; Urs, Diaconul Coresi, p. 94).

73 Păcurariu, Istoria Bisericii, I, p. 478; see also Octavian Nițu, "Relațiile dintre «Tipografia Diaconului Coresi» din Șcheii Brașovului și «Tipografia Honteriană» din Cetate”, in Biserica Ortodoxă Română 93/3-4 (1975), pp. 426-446.

74 Plămădeală, Dascăli, p. 81.

75 Gheţie - Mareş, Diaconul Coresi, pp. 43-46; Urs, Diaconul Coresi, pp. 107-108, 117-122; see also I. Gheție, "Activitatea de traducere și tipărire a cărții românești la Brașov la sfârșitul secolului al XVI-lea”, in Limba 
As a result of his collaboration with Hans Benkner, one can note that deacon Coresi and his disciples printed in Braşov several liturgical books in Savonic ${ }^{76}$. Thus, for the Small Oktoikh (Brașov, 1557) is highlighted Benkner's action, as editor ${ }^{77}$, with the purpose of using the paper manufactured in Brașov, consequently, he was pursuing commercial interests, aiming at launching an activity of cult book printing in Slavonic, and in order to realize these objectives is has been affirmed that he was testing, on the occasion of the printing of the respective Oktoikh, the skillfulness as printers of the two master printers, Oprea the Logothete and deacon Coresi. In order to assure the circulation of this book among the Romanians from the three Romanian Countries, in the Epilogue were mentioned the Ruler of Wallachia, Pătrașcu the Good, and that of Moldavia, Alexander Lăpuşneanu (15521561, 1564-1568), without their having, according to some researchers, any contribution to the printing of the respective book, not being excluded, however, the possibility that the initiative of the printing may have come from an Orthodox environment, either from Wallachia, or from the entourage of the priests from the Church of Șcheii Brașovului ${ }^{78}$. Out of the same reasons mentioned above is printed as well the Chetveroevangelie (Brașov, $1562)^{79}$, and to assure its circulation also beyond the mountains, the editor Benkner ordered the printing in the book of two frontispieces with the coat of arms of Wallachia (the raven with the cross in its beak). In this way, the book seems to have recorded a certain commercial success, since, three years later, the same editor will order a new edition of the Slavonic Chetveroevangelie (Brașov, 1565), printed, however, by clerk Călin ${ }^{80}$.

In the context of the trade of liturgical books used in the Orthodox Church, it has been affirmed that deacon Coresi, as well, was editor of certain books in Slavonic. The Slavonic Sbornik, printed by Coresi, together with five disciples, in two volumes (Braşov, 1569), also known under the title Prazdnicnaya Mineya, Festal Menaeon or Menologion, has no editor and no printing place mentioned on it. The explanation given in recent studies consists in the prudence of the supposed editor, identified as deacon Coresi, in order not to be associated to the protestant proselytism, which is why the locality where the book was printed was not written down either, since the books' origin from Brașov, a city already known as a protestant propaganda center by the printing of books, was equivalent, according to the spirit of the time, for the Orthodox believers of Wallachia and Moldavia, to the conversion to the Reformation ${ }^{81}$. In order to facilitate the distribution of the edition in Wallachia, in the Epilogue of the second volume of Sbornik ${ }^{82}$, it is mentioned that the printing took place during the reign of Prince Alexander II Mircea of Wallachia (1568-1574,

română 24/6 (1975), pp. 609-615; idem, "Sediul brașovean al tipografiei lui Coresi”, in Limba română 38/1 (1989), pp. 47-49; idem, "Din nou despre sediul brașovean al tipografiei coresiene", in Limba română 39/1 (1990), pp. 69-71.

${ }^{76}$ See Istoria literaturii române, I, București, ${ }^{2} 1964$, p. 317 (hereinafter: Istoria literaturii române, I).

77 Bibliografia românească veche, 1508-1830, vol. IV, ed. by Ioan Bianu and Dan Simonescu, Bucureşti, 1944, pp. 4-6 (hereinafter: $B R V$, IV).

${ }_{78}$ Gheţie - Mareş, Diaconul Coresi, pp. 145-146; Urs, Diaconul Coresi, pp. 219-221.

79 To these reasons one could add, according to some researchers, the reaction of Lady Chiajna, the widow of Prince Mircea Ciobanu, to the printing of the Romanian Tetraevangelion (Tetraevanghel românesc) in 1561 (see note 135 below), a reaction that would have been explicable in the context of the epoch, even though other researchers (see Gheţie - Mareş, Diaconul Coresi, p. 164) consider it a simple supposition.

${ }^{80}$ Gheţie - Mareş, Diaconul Coresi, p. 164; Urs, Diaconul Coresi, pp. 228-229.

${ }^{81}$ Urs, Diaconul Coresi, p. 234.

${ }^{82}$ The Epilogue of the first volume of this Sbornik has not been preserved (Urs, Diaconul Coresi, p. 232). 
1574-1577) and of Metropolitan Euthymius I of Hungaro-Wallachia (1563-1576), with no indication of where the printing order had come from ${ }^{83}$.

Following the same editorial policy regarding the non-indication of the person of the editor, but also of the printing place, deacon Coresi is said to have also printed in Slavonic a Sluzhebnik or Hieratikon (Braşov, 1568) ${ }^{84}$ and a Psaltir (Brașov, 1568-1570) ${ }^{85}$. In exchange, about another Psaltir in Slavonic, whose copy preserved is incomplete, it has been accepted that it was printed in Braşov, in 1572-1573, at the order of Ruler Alexander II Mircea, since his name and the coat of arms of Wallachia appear in the content of the book ${ }^{86}$. At the order of the same reigning prince, the Psaltir in Slavonic also goes through two more editions in Brașov, printed by deacon Coresi in $1568-1570$ and $1577^{87}$, not being excluded the possibility that also the edition of the Slavonic Psaltir of the year 1576, printed as well in Brașov, may have been printed at the order of the same ruler ${ }^{88}$.

Actually, deacon Coresi also executed another order of the reigning Prince Alexander II Mircea, namely the Great Oktoikh, printed in two volumes, in the years 1574 (volume I) and 1575 (volume II). The particularity of the printing of the two volumes is that in their Epilogues appears mentioned the editor, in the person of Ruler Alexander II Mircea ${ }^{89}$, for whom only deacon Coresi received printing orders ${ }^{90}$, but there is no indication of the printing place, a fact attributed by the researchers, just as in the case of other printings that deacon Coresi printed in Slavonic, to the fame of the printing center from Brassov, associated to the actions of protestant propaganda of the epoch, avoiding in this way the doubt regarding the canonicity of the texts included in the two volumes, meant for the worship

${ }^{83}$ Gheţie - Mareş, Diaconul Coresi, pp. 201-202; Urs, Diaconul Coresi, pp. 232, 234. Is not excluded either that the proposition of printing for the Slavonic Sbornik may have come from an Orthodox environment, following the connections between deacon Coresi and the Orthodox hierarchy of Wallachia (Urs, Diaconul Coresi, p. 234).

84 The version of Serbian editing used for the printing of this Sluzhebnik may represent an indication that the editor aimed to disseminate this edition in a larger area, comprising not just the Romanian Countries, but also Bulgaria and Serbia (Gheţie - Mareş, Diaconul Coresi, p. 180; Urs, Diaconul Coresi, p. 238).

${ }^{85}$ Gheție - Mareş, Diaconul Coresi, pp. 180, 185, 202; Urs, Diaconul Coresi, pp. 234, 238, 242. It seems that this Psaltire [Psalter] was destined for the South-Danubian regions as well (Gheţie - Mareş, Diaconul Coresi, p. 185).

${ }^{86}$ Gheţie - Mareş, Diaconul Coresi, pp. 185-189; Urs, Diaconul Coresi, pp. 243, 245.

${ }^{87}$ Urs, Diaconul Coresi, p. 253. It is considered that the Psalter (Psaltir in Slavonic, Psaltire in Romanian) represented the most disseminated cult book of the $16^{\text {th }}$ century, and about the editions of this book printed in Transylvania, during the second half of the same century, see also Lajos - Lidia Demény, Carte, tipar şi societate, pp. 226-248.

${ }^{88}$ Urs, Diaconul Coresi, p. 253. Other researchers attribute the quality of editor to Coresi himself for the edition of the Slavonic Psaltir of the year 1576 (Gheţie - Mareş, Diaconul Coresi, p. 191).

${ }^{89}$ BRV, I, pp. 60-61; Urs, Diaconul Coresi, pp. 248, 251. In the case of the Great Oktoikh, it has been affirmed in the Epilogues of the two volumes that the decision of the printing belongs to the reigning Prince Alexander II Mircea, who consulted, prior to it, the Metropolitan of the country, Euthymius I (BRV, I, pp. 60-61), considered, consequently, the true initiator of the printing of this book (Gheţie - Mareş, Diaconul Coresi, $\mathrm{p}$. 149). In relation to the printing of the two volumes, is attested in Braşov, on 6 June 1573, the presence of a priest sent by Ruler Alexander II Mircea for printing, and the arrival, on 12 December 1573, in the same locality, of the deacon of the bishop, namely of Metropolitan Euthymius I, for issues related to a printing press of Coresi, which confirms, on the one hand, that the printing of the two volumes represents an action of the Orthodox Church of Wallachia, and, on the other hand, the concern of the reigning prince and of the metropolitan for possessing their own printing press in Wallachia (Hurmuzaki, XI, pp. 809, 810; Urs, Diaconul Coresi, pp. 248-249; Gheţie - Mareş, Diaconul Coresi, p. 149).

${ }^{90}$ Gheţie - Mareş, Diaconul Coresi, p. 188. 
needs of the Orthodox Church in Wallachia, even though they were in Slavonic, applying the principle called act of editorial prudence $e^{91}$.

The same principle is applied for several liturgical books printed by deacon Coresi in Slavonic, as it has been shown above as well ${ }^{92}$. To these one can add other books, too, like: Slavonic Psaltir in 1577, printed by Coresi at the order of Prince Alexander II Mircea of Wallachia, joined, as editors, by his son Mihnea and Metropolitan Seraphim of HungaroWallachia (1576-1585 / 1586) ${ }^{93}$, with no indication of the printing place, which the researchers established to have been in Brașov ${ }^{94}$; Slavonic-Romanian Psaltir, in whose Epilogue Coresi speaks about the addressees of the book, and also about the reasons for printing this book in Slavonic and Romanian ${ }^{95}$, without mentioning, however, the place where the printing took place ${ }^{96}$. The intentional omission of mentioning the printing locality, identified by the researchers as Brașov, is due to the Romanians' susceptibility to the noncanonicity of the books from Brașov ${ }^{97}$. Even though the Slavic-Romanian Psaltir of the year 1577 was not explicitly put in the service of some action meant to convert the Romanians to Protestantism, but was probably destined to the learning of the Slavonic language in schools $^{98}$, such as that of the Saint Nicholas Church in S,cheii Brașovului ${ }^{99}$, it indicated, beside the teaching aim, also the aim of demonstrating that the version in Romanian was just as authentic as the one in Slavonic, in other words, the Lutherans wanted to convince the Romanians that there was no dogmatic difference between the two versions, except for the

${ }^{91}$ Gheţie - Mareş, Diaconul Coresi, pp. 43, 147-148; Urs, Diaconul Coresi, pp. 246, 248, 250; Ion Gheție, Al. Mareș, Originile scrisului în limba română, București, 1985, p. 103.

92 Actually, out of the books in Slavonic printed by deacon Coresi only the Small Oktoikh of the year 1557, the Postnaya Triod-Tsvetnaya Triod of 1558, the Chetveroevangelie of 1562 and the Sbornik of 1580 mention the place where their printing was realized (Urs, Diaconul Coresi, p. 262).

93 The quality of co-editor attributed to Mihnea is due, according to some researchers, to the fact that Alexander II Mircea had passed into the life beyond the grave on 25 July 1577, a date when the printing of the book had not been finished, as it was concluded before 24 August 1577, when the Postnaya Triod, also called Lenten Triodion, begins to be printed, (Braşov, 1578). It is considered that the initiative regarding the printing of the Slavonic Psaltir of 1577 belonged to Metropolitan Seraphim of Hungaro-Wallachia, and the coat of arms or the emblem of Wallachia (the raven with a cross in its beak) in the frontispiece and in the laurel crown confirms the reigning prince's order and the area of destination of this book (Gheţie - Mareş, Diaconul Coresi, p. 193; Urs, Diaconul Coresi, p. 257).

${ }^{94}$ Gheţie - Mareş, Diaconul Coresi, p. 193; Urs, Diaconul Coresi, p. 255.

${ }^{95}$ Deacon Coresi highlights, in the Epilogue of the book, that he was burning with the zeal that the Romanians, too, should have the word of God in their language, as all the languages had it, namely all the peoples, which is why he printed the translation from the Slavonic Psaltir in the Romanian language, so that, printed in a bilingual text, in Slavonic and Romanian, the Psalter may be for the clerks (grammatikoí) to understand, but also for the believers to observe, who, by reading it, should understand that it is real (BRV, I, pp. 63-64). For the same reason, namely to show the capacity of the Romanian language to render the biblical texts without distorting their meaning, Saint Dosoftei uses the same method of deacon Coresi, printing in a bilingual text, Slavonic and Romanian, Psaltir for understanding (Psaltirea de-nțăles, Iași, 1680; see BRV, I, p. 226), later on, the brothers Radu and Șerban Greceanu will print the Greek-Romanian Gospel (Evanghelia greco-română, București, 1693; BRV, I, p. 328), and Saint Anthim the Iberian, before moving on to the printing of certain liturgical books only in the Romanian language, will issue bilingual (Slavic-Romanian) and trilingual editions (Slavic-Greek-Romanian), see Ion I. Croitoru, "Sfântul Ierarh Martir Antim Ivireanul (1650-1716), mitropolitul Țării Românești”, in Croitoru, Ortodoxia și Apusul, I, pp. 354-355; idem, "Folosirea tiparului în Țările Române pentru apărarea Ortodoxiei în fața propagandei protestante”, in Croitoru, Ortodoxia și Apusul, II, p. 723 (hereinafter: Croitoru, Folosirea tiparului).

${ }^{96}$ Urs, Diaconul Coresi, p. 213.

${ }^{97}$ Urs, Diaconul Coresi, p. 214.

${ }^{98}$ Gheţie - Mareş, Diaconul Coresi, p. 259.

${ }^{99}$ Urs, Diaconul Coresi, p. 214 . In this sense, see above, in note 72 , the mention of deacon Coresi. 
language in which they were printed, and for this reason the editor, considered to be part of the reformed environment of Braşov, is not mentioned, remaining unknown ${ }^{100}$. The same didactic aim could be affirmed, yet with some reserves, also about The Gospel with teaching (Evanghelia cu invățătură) of 1581, although its "decision maker" is Lukas Hirscher, the judge of Braşov, who influenced the elimination, from the book summary, of a sermon that expressed perspectives contrary to the protestant doctrine ${ }^{101}$; Postnaya Triod, also called Lenten Triodion, printed in 1578, as it is specified in the Epilogue $e^{102}$, without indicating the place of publication, which the researchers establish as Brașov ${ }^{103}$. The printing of this book in Slavonic is done at the order of Ruler Alexander II Mircea and of his son Mihnea ${ }^{104}$, without indicating Metropolitan Seraphim anymore. However, the printing of the Triodion is due precisely to the cultural and ecclesial environment represented by Metropolitan Seraphim, who, in collaboration with the reigning Prince Alexander II Mircea, takes care of the printing of several books necessary to the worship of the Orthodox Church in Wallachia $^{105}$. The death of Alexander II Mircea (25 July 1577) before the beginning of the printing of this book (the printing activity begins on 24 August 1577 and ends on 26 March 1578) shows that the order to print the respective book was given simultaneously to the order for the Slavonic Psaltir of 1577. The bringing to completion of the respective order is due to the fact that Mihnea ${ }^{106}$, mentioned next to his father as editor, took over, along with the princely throne, the cultural-editorial commitments assumed by his father ${ }^{107}$; Chetveroevangelie, which was printed in 1579, a date indicated in the Epilogue of the book $^{108}$, with no mention of the printing place, deduced from complementary sources to have been Brașov ${ }^{109}$. The editors of this liturgical book are, as it results from the Epilogue, deacon Coresi and Mănăilă ${ }^{110}$, they being also the printers of the respective book ${ }^{111}$. This edition of the Tetraevangelion in Slavonic is not placed under any princely or ecclesial authority, the initiative of the printing coming exclusively from the two typographers, who assured, inasmuch as the Epilogue lets one understand, also the common financial support, being

${ }^{100}$ Urs, Diaconul Coresi, p. 216. In relation to the editor's person, is launched the supposition that it could have been a person of the Benkner family, since in Petrus Schirmer's succession act figure three copies of a SlavicRomanian Psaltir, and it could have been even the 1577 edition. Given the anonymous identity of the editor and of the place, the edition meant for the clerks of Slavonic language was sold well, since the succession act mentions only three copies remained unsold [Urs, Diaconul Coresi, pp. 216-217; see also Gernot Nussbächer, "Tipărituri românești menționate într-un act de partaj din 1585", in Limba română 39/5-6 (1991), p. 75].

${ }^{101}$ Gheţie - Mareş, Diaconul Coresi, pp. 112, 260.

${ }^{102}$ BRV, I, p. 69; Urs, Diaconul Coresi, p. 257.

${ }^{103}$ Gheție - Mareş, Diaconul Coresi, p. 157; Urs, Diaconul Coresi, p. 258.

${ }^{104} B R V$, I, p. 69.

${ }^{105}$ In the same context of protestant propaganda, yet coming to meet the needs of the Orthodox Church in Wallachia, and of the Orthodox believers of Slavonic language, can also be included the printing by Coresi of the Postnaya Triod-Tsvetnaya Triod in Târgovişte, in 1558 (Gheţie - Mareş, Diaconul Coresi, pp. 37, 152$155)$.

${ }^{106} \mathrm{He}$ is known in history by the name of Mihnea II the Turcized [(1574-1577, associated to the reign of his father, Alexander II Mircea), 1577-1583, 1585-1591], given his conversion to the Islam, after the loss of his reigns, in the attempt to return to the throne of Wallachia.

${ }^{107}$ Gheţie - Mareş, Diaconul Coresi, p. 157; Urs, Diaconul Coresi, p. 260.

${ }^{108}$ Urs, Diaconul Coresi, p. 261.

${ }^{109}$ Gheţie - Mareş, Diaconul Coresi, p. 167; Urs, Diaconul Coresi, p. 262.

${ }^{110}$ BRV, I, p. 74.

${ }^{111}$ BRV, I, pp. 74-75; Gheţie - Mareş, Diaconul Coresi, p. 167; Urs, Diaconul Coresi, p. 264. 
attracted by the success of the circulation of the Slavonic liturgical books printed previously and, implicitly, by the profit made by trading the respective books ${ }^{112}$.

In the same year 1579, clerk Lorint prints in Alba Iulia another edition of the Slavonic Chetveroevangelie, at the order of Prince Christopher Báthory (1576-1581). It seems that between the two editions there was commercial rivalry, even though Coresi's edition was meant for Wallachia, for which he had printed liturgical books in Slavonic before, whereas the copies of Lorint were destined for Transylvania. To prevent the printing of a new edition of the Tetraevangelion, which could have made it harder to sell the copies of the edition from Alba Iulia, Prince Christopher Báthory forbids the reediting of the Slavonic Chetveroevangelie for 30 years $^{113}$. The demand of this book must have been great, because, despite this interdiction, it can be noticed that two more editions of the Slavonic Chetveroevangelie are printed in a relatively short while, respectively three and four years later: the first at Plumbuita Monastery, at the initiative of hieromonk Lavrentie, in $1582^{114}$; the second in Brașov, at the order of Prince Peter Earring of Wallachia, in $1583^{115}$. In the Epilogue of the edition of the Chetveroevangelie of 1583 it is mentioned that the printing of the book took place at the order of Peter Earring, during the first year of his reign ${ }^{116}$, namely during the last months of the year 1583, which would mean that the initiative of the printing either belongs to Coresi, who could have obtained the approval of Prince Peter Earring, by virtue of the tradition of his family ${ }^{117}$, or that the discussions with a view to printing the book were initiated by Peter Earring before his enthronement, with the result that, the moment he was anointed as a reigning prince, deacon Coresi and Mănăilă begin to execute the new order, concluded, maybe, during the time when the priests of Șcheii Brașovului were asking for the ruler's help to beautify Saint Nicholas Church ${ }^{118}$. Thus, the fact that the new ruler is preoccupied, immediately after his enthronement, by the printing of a liturgical book, can be an indication that this action was one of the priorities that he had set for himself the moment he was appointed as reigning prince ${ }^{119}$. It ought to be mentioned that the printing location was not mentioned for this book either, being established by the researchers as Brașov, and it is believed that this thing happened, as well, as a consequence of the reasons and of the principle presented above ${ }^{120}$. Totally different was the framework of the printing of the Slavonic Sbornik, about which we know, from the Epilogues of the two editions ${ }^{121}$, some

112 Gheţie - Mareş, Diaconul Coresi, p. 167; Urs, Diaconul Coresi, p. 264.

${ }^{113}$ BRV, I, p. 75; Gheţie - Mareş, Diaconul Coresi, p. 168. The act of Prince Christopher Báthory represents, at the same time, also a monopoly for the printing of a liturgical book granted for the first time to a printer of the Romanian Countries (see also above, note 34 ).

114 The hieromonk Lavrentie, together with his disciple Iovan, printed the Slavonic Chetveroevangelie in two editions, out of which one in 1582, and another at a date that cannot be identified precisely (Urs, Diaconul Coresi, p. 75).

${ }^{115}$ Gheţie - Mareş, Diaconul Coresi, p. 168.

${ }^{116} B R V$, I, p. 99.

117 The forerunners of Prince Peter Earring, his great-grandfather, his grandfather and his father, namely Rulers Radu the Great, Radu Paisie and Pătraşcu the Good, contributed, each of them, to the promotion and support of the printing press in Wallachia (Gheţie - Mareş, Diaconul Coresi, p. 170).

118 Gheţie - Mareş, Diaconul Coresi, p. 170; Urs, Diaconul Coresi, pp. 273-274.

${ }^{119}$ Urs, Diaconul Coresi, p. 273.

${ }^{120}$ Gheţie - Mareş, Diaconul Coresi, p. 170; Urs, Diaconul Coresi, pp. 271-272.

${ }^{121}$ It should be mentioned that the two editions of the Slavonic Sbornik highlighted above are, nevertheless, different, the first relying on several sources, and the second being more faithful to the edition of the Prazdnicnaya Mineya printed in Venice, in 1538, by Božidar Vukovič, see Gheţie - Mareş, Diaconul Coresi, pp. 201, 205-206. 
technical data: the year, 1580; the printing place, Sas-Sebeș; the printer, Coresi; the commissioner or financial supporter, Metropolitan Ghenadie; the original after which Coresi prints the book, namely the edition of "Bojidar" (Božidar Vukovič), actually the Prazdnicnaya Mineya or Festal Menaeon printed in Venice, in $1538^{122}$. The intervention of deacon Coresi in the text of this Sbornik, which is in Slavonic of Serbian redaction, can be noticed by the identification of certain linguistic phenomena specific of the Medio-Bulgarian redaction, being considered to belong to him $^{123}$, and author of the Epilogues is considered to be the Metropolitan of Transylvania Ghenadie I (1579-1585) ${ }^{124}$, in which he was drawing the believers' attention to the Reformation, affirming that in the latter times he had seen, from the peoples of other faiths, great damage and fall of the holy churches ${ }^{125}$.

The publication of the Slavonic Sbornik represents the first editorial action undertaken during that time by the Orthodox Metropolitanate of Transylvania ${ }^{126}$, an event to which several facts will contribute: the attenuation of the pressure of the protestant propaganda, because on 21 October 1579, following the death of the Metropolitan of Transylvania Christopher II (appointed on 6 June 1574 and falling asleep in the Lord before 16 May 1579), the Diet of Turda decided that the Romanian priests should elect as their bishop whomever they want ${ }^{127}$; the policy of religious tolerance promoted by prince Christopher Báthory, observable as well by the fact that the printing of the Sbornik takes place in his time, with his approval, which also explains the presence of his coat of arms at the end of the volume, as an expression of the praise given to him by the editor and the printer $^{128}$; the exhortations received by Metropolitan Ghenadie I from Metropolitan Seraphim of Hungaro-Wallachia, on the occasion of the cheirotonia and cheirothesia of the first in Târgoviște as Bishop and Metropolitan of Ardeal, regarding the defense of the Orthodox faith in front of the actions of the protestant propaganda in Transylvania, among them being enumerated the printing of books destined to the worship of the Orthodox Church in Slavonic ${ }^{129}$.

The choice of the printing place of the Slavonic Sbornik in Sas-Sebeș, beside the explanations that have already been given by the researchers ${ }^{130}$, can also be due to the prestige that the printing centers of Alba Iulia and Brașov already enjoyed, as places of propagation of the protestant doctrine by means of printed books, and to avoid any suspicions, according to the principle of editorial prudence, reminded above as well, the

${ }^{122}$ BRV, I, pp. 81-85; Urs, Diaconul Coresi, pp. 265-266, 269.

${ }^{123}$ Gheţie - Mareş, Diaconul Coresi, p. 206; Urs, Diaconul Coresi, p. 269. It has been affirmed that deacon Coresi was already thinking about a possible reprinting of the edition of Božidar Vukovič before the election of Ghenadie as metropolitan (Gheţie - Mareş, Diaconul Coresi, p. 207).

${ }^{124}$ Urs, Diaconul Coresi, p. 269.

${ }^{125}$ BRV, I, p. 84; Croitoru, Propaganda protestantă, p. 483, note 95.

${ }^{126}$ Gheţie - Mareş, Diaconul Coresi, p. 207.

${ }^{127}$ Meteș, Istoria Bisericii, p. 94.

${ }^{128}$ Urs, Diaconul Coresi, p. 269.

${ }^{129}$ Urs, Diaconul Coresi, p. 269.

${ }^{130}$ An explanation is related to the position and intervention of pastor Johannes Scherer-Nyirö, owner of the Latin printing press of Brașov, between 1580 and 1581, who could have mediated the temporary settlement of Coresi's printing press at Sas-Sebeș. Another explanation for the printing of the book in Sas-Sebeș has in view the possibility of the active participation of Ioan Norocea the Logothete, a political personality of the time and an acquaintance of Metropolitan Ghenadie I, who was living in that town and could have assured or facilitated the finding of a place for the installation of Coresi's printing press, and may have also provided financial help for the printing of the book that the Romanian hierarch needed (Gheţie - Mareş, Diaconul Coresi, p. 205; Urs, Diaconul Coresi, p. 265). 
locality Sas-Sebeș was chosen. Moreover, this choice also offered the advantage of the fact that the respective locality was close to Alba Iulia, where the Orthodox Metropolitanate of Transylvania had its headquarters ${ }^{131}$, giving to Metropolitan Ghenadie I the possibility to supervise the process of printing for the Slavonic Sbornik ${ }^{132}$. The book enjoyed a large circulation among the Romanians of the three Romanian Countries, but also in the areas of the Orthodox world of Slavonic language ${ }^{133}$.

Based on the same collaborations with Hans Benkner, in Brașov were printed books in Romanian as well: Intrebare creştinească (Christian Question, 1560) ${ }^{134}$; Tetraevanghel (Tetraevangelion) or Evangheliar (Evangelion, 1561) ${ }^{135}$; Pravila Sfinţilor Apostoli (Pravila or The Nomocanon of the Holy Apostles), also known as Pravila Sfinților Părinți (Pravila or

131 The headquarters of the Metropolitanate had been moved, during the pastoral activity of the Metropolitan Euthymius I of Ardeal (1571-1574), from Lancrăm to Alba Iulia, where the headquarters of the Prince of the country and of the Hungarian Calvinist superintendent were, yet outside the city walls, because the Orthodox were forbidden to express their worship inside the city [Ion I. Croitoru, "Biserica Ortodoxă din Transilvania", in Croitoru, Ortodoxia și Apusul, I, p. 219, note 86; Mircea Păcurariu, Istoria Bisericii româneşti din Transilvania, Banat, Crişana şi Maramureş, Cluj-Napoca, 1992, p. 130 (hereinafter: Păcurariu, Istoria Bisericii româneşti din Transilvania)].

${ }^{132}$ Gheţie - Mareş, Diaconul Coresi, p. 205.

133 Urs, Diaconul Coresi, p. 270. It should be mentioned that the Slavonic Sbornik of 1580 also contains the Pripeale by Philotheos the Monk, short hymnographic texts (magnifications, velichanii in Slavonic) which are sung with verses of the Psalms at the Polyeleos of the great feasts in honor of Jesus Christ, of the Theotokos and of some Saints. Printed for the first time in Slavonic in the edition of the Slavonic Sbornik of Venise in 1536, and in Romanian in the Psalter (Psaltirea) of Buzău in 1703, their author being identified as Filos (Philos) the Logothete of the reigning Prince of Wallachia Mircea the Elder or the Great (1386-1418), they continue to be used to this day in the worship of the Orthodox Church of Romania (Ion I. Croitoru, "Scriptorii", in Croitoru, Ortodoxia și Apusul, I, p. 240, note 43).

${ }^{134}$ While in the specialized literature it had been consecrated that the work Christian Question (Intrebare creştinească) was printed in 1559 , other propositions existing as well, recent studies have established that the respective book was printed in 1560, in Brașov, see Alexandra Roman Moraru, "Studiu filologic. Introducere", in Texte românești din secolul al XVI-lea. I. Catehismul lui Coresi. II. Pravila lui Coresi. III. Fragmentul Todorescu. IV. Glosele Bogdan. V. Prefețe și epiloguri, critical editions by Emanuela Buză, Gheorghe Chivu, Magdalena Georgescu, Ion Gheție, Alexandra Roman Moraru, Florentina Zgraon, coordinator Ion Gheție, București, 1982, pp. 32-33, 38-39 (hereinafter: Moraru, Studiu filologic); Gheţie - Mareş, Diaconul Coresi, pp. 38, 56-57; Urs, Diaconul Coresi, pp. 141-143.

${ }^{135}$ Gheţie - Mareş, Diaconul Coresi, pp. 38, 67-79; Urs, Diaconul Coresi, pp. 149-156. Given the fact that the printing in Romanian was realized under the patronage of a Lutheran, due to whose influence the Christian Question (Intrebare creştinească) had also been printed, this Tetraevangelion (Tetraevanghel), printed in at least two editions (Urs, Diaconul Coresi, p. 150), in 1561, triggered the Romanians' reaction both in Transylvania, and in Wallachia. This would explain the appearance of the edition in Slavonic of the same book (Slavonic Chetveroevangelie, Braşov, 1562; see BRV, I, p. 46; Păcurariu, Istoria Bisericii, I, p. 479; Gheţie Mareş, Diaconul Coresi, pp. 38, 161-164), a year later, also under Benkner's patronage, which meant a deviation from the program of the Lutheran propaganda among the Romanians. This edition was also due, according to some researchers, to the intervention of Lady Chiajna, the widow of Prince Mircea the Shepherd of Wallachia (1545-1552, 1553-1554, 1558-1559), also as a reaction to the printing of the translation in Romanian of the Tetraevangelion (Tetraevanghel) of 1561 , but also to the intentions of the editor Hans Benkner to cover his expenses made on the occasion of the printing of the Christian Question, remained in the warehouses of the printing press of Braşov [Gr. Scorpan, "Locul Cazaniei lui Varlaam în vechea noastră literatură omiletică din sec. XVI şi XVII”, in Cercetări Istorice (Iași) 13-14/1-2 (1940), p. 547 (hereinafter: Scorpan, Locul Cazaniei lui Varlaam); Gheţie - Mareş, Diaconul Coresi, pp. 38, 161-164; Urs, Diaconul Coresi, pp. 228-229; for the editing of the book, see Tetraevanghelul tipărit de Coresi, Brașov 1560-1561, comparat cu Evangheliarul lui Radu de la Mănicești, 1574, an edition arranged by Florica Dimitrescu, București, 1963]. 
The Nomocanon of the Holy Fathers, 1560-1562) ${ }^{136}$, whose title is considered to have been Pravilă de ispravă oamenilor și de toate păcatele și greșalele (Pravila or The Nomocanon for the men's triumph and for all the sins and the mistakes) ${ }^{137}$; and Lucrul apostolesc (The Apostolic Work) or Apostol (Apostolos), also called Praxiu (Praxis, 1566) ${ }^{138}$. This action of printing of books in Romanian, beside the economic interest, cannot be dissociated, according to the analysis of the events specific of that epoch, from the attempts of the Saxons from Brassov to attract the Romanians to the Reformation ${ }^{139}$, especially since one of the protestant principles, met as motivation in the Romanian printings of deacon Coresi, was that all the peoples should know the word of God in their own language $e^{140}$.

In the book Christian Question (Întrebare creștinească), a printing known in the specialized literature also under the title Catechism $^{141}$, protestant influences were slipped in, which explains the fact that the initiative of the printing of this Catechism had belonged to the judge of Brașov, Hans Benkner, and to the Council of the respective city in May $1559^{142}$. Considered an edition affiliated to the Catechism of $1544^{143}$, the Orthodox teaching from the Christian Question, in whose Preface was shown that the translation, dedicated to Metropolitan Ephrem of Hungaro-Wallachia (1558-1566), was realized with the knowledge of Prince John II Sigismund Zápolya and of the Metropolitan of Transylvania Sava I (15591561, 1562-1570), called by Coresi Bishop of the Hungarian Country ${ }^{144}$, was reduced, under the form of a dialogue in 28 questions and answers, to the commandmants of the Decalogue, rendered under a Lutheran form, the Niceo-Constantinopolitan Symbol of Faith without Filioque, considered however mistakenly, as the faith formulated by the 12 Apostles, The Lord's Prayer and two Mysteries or Sacraments: the Baptism and the Holy Communion; the Holy Tradition was rejected; it was confessing the faith without actions (sola fide), the fact of being made right with God and being made worthy of Christ's grace only by remembering God's acts, with no other spiritual effort from the Christian; the veneration of the Lord's Mother and of the Saints was rejected, some researchers also highlighting some possible

136 Gheţie - Mareş, Diaconul Coresi, pp. 38, 80-89; Urs, Diaconul Coresi, pp. 156-163; Păcurariu, Istoria Bisericii, I, p. 480; see also Gheorghe Chivu, "Studiu filologic. Introducere", in Texte românești din secolul al XVI-lea. I. Catehismul lui Coresi. II. Pravila lui Coresi..., pp. 137-141.

${ }^{137}$ Urs, Diaconul Coresi, p. 158.

138 Gheție - Mareş, Diaconul Coresi, pp. 90-101; Urs, Diaconul Coresi, pp. 163-171; Ivaşcu, Istoria, p. 102; Istoria literaturii române, I, p. 308. It should be mentioned that, in the specialized literature, several dates have been proposed for the printing of the Apostolos, during the period 1563-1566, but finally the year 1566 has been accepted [see P. Binder, Arnold Huttmann, "Cu privire la datarea şi geneza Cazaniei I tipărită de diaconul Coresi”, in Limba română 16/2 (1967), p. 117 (hereinafter: Binder - Huttmann, Datarea și geneza Cazaniei I); Gheție - Mareş, Diaconul Coresi, pp. 39, 91-92; Urs, Diaconul Coresi, p. 164].

${ }^{139}$ Gheţie - Mareş, Diaconul Coresi, pp. 75, 259.

${ }^{140}$ Urs, Diaconul Coresi, p. 107.

${ }^{141}$ Called even Lutheran Catechism (Lajos - Lidia Demény, Carte, tipar și societate, p. 328). For the text in Cyrillic and in Romanian transcription of the Christian Question, see Crăciun, Catechismul românesc din 1544, pp. 39-68; see also the text established in interpretative transcription by Alexandra Roman Moraru in Texte românești din secolul al XVI-lea. I. Catehismul lui Coresi..., pp. 101-105.

${ }^{142}$ Lajos - Lidia Demény, Carte, tipar și societate, p. 328. It has been affirmed that during the same year, on 12 March, the City Council of Brașov, under the patronage of Hans Benkner, decided to reform the Church of the Romanians from Șchei and proposed or imposed the learning of the Catechism that will be printed by Coresi in 1560 (Gheţie - Mareş, Diaconul Coresi, p. 259; Urs, Diaconul Coresi, p. 141; Florica Dimitrescu, "Introducere", in Tetraevanghelul tipărit de Coresi, Braşov 1560-1561..., 1963, p. 10).

${ }^{143}$ Crăciun, Catechismul românesc din 1544, pp. 1-2, 22; Moraru, Studiu filologic, pp. 49-52; Gheţie - Mareş, Diaconul Coresi, pp. 61-62.

${ }^{144}$ Gheţie - Mareş, Diaconul Coresi, pp. 38, 56. 
Zwinglian - Antitrinitarian orientations in the content of the respective book ${ }^{145}$. In the Preface or the Prologue of the book was stipulated the protestant principle according to which God's word, namely the Holy Scripture, must be disseminated in the language of each nation, to be known by all the people ${ }^{146}$. This principle will also be met in the Epilogues of other printings, becoming, therefore, a typically Coresian expression ${ }^{147}$.

Based on the success of the printing of such a book, including in its content protestant innovations, Benkner announced pompously that he had reformed the Wallachians' Church $^{148}$, and to assure its dissemination among the Orthodox Romanians not just of Transylvania, but also from Wallachia, despite the respective innovations which represented teachings that were foreign to the Orthodoxy, in the Prologue were written the names of the Metropolitans of Transylvania and Wallachia, Sava I and Ephrem ${ }^{149}$. It should be mentioned that the arrangement of the version for the Christian Question of 1560 and that for the Romanian Tetraevangelion of 1561 took place simultaneously, giving priority to the printing of the Catechism, a fact imposed by the decision of the City Council of the Saxons of Brașov to attract the Romanians to the Reformation ${ }^{150}$.

Thus, one can note that, both in Sibiu and in Brașov, the first printed books dedicated to the Romanians were a Catechism and a Tetraevangelion, which indicates the reformed environment that determined their appearance, on the one hand, under the aspect of propaganda, in the case of both of these books, aiming not just to seep in the protestant innovations, but also to nationalize the worship of the Orthodox Church, and, on the other hand, to promote the economic-commercial aspect of the printing activity, as far as the last book is concerned ${ }^{151}$. These aspects, namely the nationalization of the cult and the financial gain, determined Hans Benkner to be also the editor of the Nomocanon or Pravila, not being excluded, in the case of this book, the initiative of the Orthodox Church of Transylvania for

${ }^{145}$ Moraru, Studiu filologic, pp. 44-45, 46-49; Gheţie - Mareş, Diaconul Coresi, p. 56, 60, 62-64; Urs, Diaconul Coresi, p. 144. It is supposed that this book also circulated in manuscripts, since a copy made in 1607 by priest Grigorie of Măhaciu has been preserved, being called Sturdzan Catechism, according to the name of the codex in which it was found, and another one in the Marțian Codex (Crăciun, Catechismul românesc din 1544, p. 22; Păcurariu, Istoria Bisericii, I, p. 480; Gheţie - Mareş, Diaconul Coresi, p. 306). For the text of the Sturdzan Catechism in Cyrillic and its Romanian transcription see Crăciun, Catechismul românesc din 1544, pp. 69-95, and for the analysis of the content of the book printed by Coresi, its sources and its historical context, see also N. Şerbănescu, «La 400 de ani de la apariţia „Întrebării creștineşti”», in Biserica Ortodoxă Română 77/11-12 (1959), pp. 1033-1052; for a bibliography of the research up to 1974, see Gheorghe Chivu, Marian Costinescu, Bibliografia filologică românească. Secolul al XVI-lea, București, 1974, pp. 110-114. In recent studies it has been stated that the Christian Question is similar, as form (given its division in five parts), to the Small Catechism (1529) of Luther and other protestant Catechisms (some in Hungarian), without the possibility, however, of establishing precisely either the original or the main source of the translation, or the person of the translator (Gheţie - Mareş, Diaconul Coresi, pp. 56, 59-61; Urs, Diaconul Coresi, p. 144-146; Moraru, Studiu filologic, pp. 48-54). About different reeditions of the Christian Question, see Gheţie - Mareş, Diaconul Coresi, p. 56; Urs, Diaconul Coresi, p. 141.

${ }^{146}$ BRV, IV, pp. 6-7; Urs, Diaconul Coresi, p. 145.

${ }^{147}$ Urs, Diaconul Coresi, p. 145.

${ }^{148}$ Molin, Circulaţia unui ,catehism vechi”, p. 367.

${ }^{149}$ BRV, IV, pp. 6-7; Istoria literaturii române, I, p. 310; Nicolae Cartojan, Istoria literaturii române vechi, Bucureşti, ${ }^{3} 1996$, pp. 101-102 (hereinafter: Cartojan, Istoria literaturii); Păcurariu, Istoria Bisericii, I, pp. 479 480; Gheție - Mareş, Diaconul Coresi, p. 56; Urs, Diaconul Coresi, p. 144.

${ }^{150}$ Urs, Diaconul Coresi, pp. 147-148.

${ }^{151}$ Urs, Diaconul Coresi, pp. 148, 156; Moraru, Studiu filologic, pp. 37-39; 54-55; see also Al. Rosetti, "Despre data primelor traduceri românești de cărți religioase și despre curentele literare din secolul al XVI-lea", in Limba română 10/3 (1961), pp. 241-245. 
the printing of this Nomocanon, more precisely of the priests from the Church of Șchei, since the respective book, by its triple role, namely didactic, normative and juridical, was specific of the Orthodox tradition ${ }^{152}$. In the same Lutheran environment and for the same reasons mentioned above was also printed the Apostolos, editor being a person of the family of Johannes or Hans Benkner, who died in $1565^{153}$.

The Lutheran Lukas Hirscher, the judge of Braşov, patronizes, in 1581, the printing of the book Evanghelia cu învătătură (The Gospels with teaching ${ }^{154}$, to a lesser extent out of denominational considerations, since in the Preface of the book was attacked the protestant doctrine itself ${ }^{155}$, but rather out of economic reasons ${ }^{156}$. Actually, the book emerges, on the one hand, as a work resulting from the collaboration of the hierarchs and priests of Transylvania and Wallachia, but also as a form of local, yet at the same time modern, ecumenism, if we consider the person of the one under whose patronage the printing of the book took place ${ }^{157}$. On the other hand, the emergence of this book, in the context of the protestant propaganda, under whose influence several sermons with a markedly Orthodox content are eliminated, means that the representatives of this propaganda changed their tactics, namely, in the case of the respective book, they acted by omitting or eliminating the specifically Orthodox points of view, avoiding, at the same time, introducing protestant principles in the content of the book ${ }^{158}$.

Out of the Prologue of the book printed in Brașov ${ }^{159}$ we find out that Lukas Hirscher discussed with the Metropolitan of Transylvania Ghenadie I and with many priests of the clergy who needed this book, then, having the approval of Metropolitan Seraphim of Wallachia, from whom they had received the original in Slavonic ${ }^{160}$, gave the book to

152 Urs, Diaconul Coresi, pp. 161-162; Gheorghe Chivu, op. cit., p. 161.

153 Urs, Diaconul Coresi, pp. 170-171. In the succession act of the year 1585 concerning the heirs of Petrus Schirmer, son-in-law of Benkner's daughter, Agnesa Hüterin, is mentioned the finding of 11 copies of this book in Schirmer's property, which, being unsold, were going to be shared among his children. The mention of the Apostolos in the succession act can be a proof of the fact that deacon Coresi collaborated as well with the other members of the Benkner family (Urs, Diaconul Coresi, p. 171).

${ }^{154}$ It ought to be specified that, in the specialized literature, The Gospels with teaching is also cited under the title Cazania II (Kazania or Homiliary II), to discern it from another printing of Coresi, namely The Interpretation of the Gospels (Tâlcul Evangheliilor), known as Cazania I (Kazania or Homiliary I) [Ion Gheție, "Studiu introductiv" (hereinafter: Gheție, Studiu introductiv), in Coresi, Tâlcul Evangheliilor şi Molitevnic rumânesc, critical edition by Vladimir Drimba, with an introductory study by Ion Gheție, București, 1998 (hereinafter: Coresi, Tâlcul Evangheliilor), p. 9]. For the last edition of The Gospel with teaching, printed under the title Carte cu învățătură (Book with teaching), being, in fact, an anastatic reproduction of the edition of the year 1914, see Diaconul Coresi, Carte cu învățătură (1581), vol. I, Textul, Editura Tipo Moldova, Iași, 2011 (this edition has many shortcomings).

155 Păcurariu, Istoria Bisericii, I, pp. 478-479. For instance, it fought the protestant doctrine about sola fide, with evidence from the Holy Scripture, showing the value of faith and good deeds, in direct relation with a righteous life, and much endeavour for the one who wants to enter the Kingdom of Heaven, because faith without deeds is truly dead (BRV, I, p. 90).

${ }^{156}$ Lupaş, Istoria bisericească, p. 53; Păcurariu, Istoria Bisericii, I, p. 478.

${ }^{157}$ Croitoru, Propaganda protestantă, p. 478; see also I. Ionescu, "Patru sute de ani de la tipărirea Evangheliei cu învățătură de diaconul Coresi la Brașov în 1581 și mesajul ce-1 poartă”, in Glasul Bisericii 40/11 (1981), p. 315; Urs, Diaconul Coresi, p. 209.

${ }^{158}$ Urs, Diaconul Coresi, p. 210.

${ }^{159}$ Urs, Diaconul Coresi, p. 203.

${ }^{160}$ Recent studies have shown that The Gospels with teaching was a translation of the Byzantino-Slavic sermons collection, printed in Slavonic at Zabludów, in 1569, at the request of Gregory Chodkiewicz or Khodkevych, hetman of Lithuania, using, nevertheless, other sources as well [Păcurariu, Istoria Bisericii, I, p. 483; Dan Zamfirescu, "Cuvântul editorului”, in Florentina Gaftoi-Holtea, Mitropolitul Varlaam şi Damaschin 
deacon Coresi, who together with the priests Iane and Mihai from Saint Nicholas Church of Şcheii Braşovului, translated it in Romanian and printed it ${ }^{161}$. By this reminder, the Lutheran editor wanted to give authenticity to the book and confidence that it is in harmony with the Orthodox teaching, being meant not just for the Orthodox Romanians of Transylvania, but also for those of Wallachia, assuring, at the same time, a much larger dissemination of this book $^{162}$. Specialized studies have contested Coresi's work as a translator, being considered only printer of the respective edition or printer-corrector ${ }^{163}$, while the two priests from the church of Șcheii Brașovului, which church had been temporarily caught, during that period, in the protestant propaganda ${ }^{164}$, did only the translation of those sermons for which they had no older versions available. For the rest, they must have reviewed existing translations, by putting them face to face with the corresponding texts from "Kazania" of Zabludów ${ }^{165}$.

The Slavonic text of Zabludów (1569) had been meant for the Orthodox people of Ukraine and Lithuania, exposed to the Roman-Catholic propaganda ${ }^{166}$, and the Romanian translation was addressed, at that moment of the history of the Orthodoxy, mainly to the Romanians of Transylvania, who had to face a different propaganda, namely the protestant one. Yet, from the Romanian edition of the comments or sermons to the evangelical pericopes of the Sundays over the year and of some feasts, pericopes reproduced after the Tetraevangelion of 1561 and which begin with the Sunday of the Publican and the Pharisee and end with the $32^{\text {nd }}$ Sunday after the Pentecost, are missing the sermons for several great feasts in honor of our Lord Jesus Christ, Savior of the world, and His Holy Mother and of some better known Saints, and for some Sundays (for six Sundays), including the Sunday of the Orthodoxy ${ }^{167}$, and at the end of the book, which comprises 66 sermons ${ }^{168}$, have been added, due to the book editor, The Lord's Prayer, The Symbol of Faith and The Decalogue or The Ten Commandments, as they had appeared in a Lutheran Catechism in Sibiu, in

Studitul, Bucureşti, 2006 (hereinafter: Gaftoi-Holtea, Mitropolitul Varlaam), pp. 10-11 and note 1 from pp. 158166; Maria Rădulescu, Originalul slav al „Evangheliei cu învățătură” a diaconului Coresi, București, 1959, pp. 10-33; P. Olteanu, "Les originaux slavo-russes des plus anciennes collections d'homélies roumaines", in Romanoslavica 9 (1963), pp. 163-193; Urs, Diaconul Coresi, pp. 205-207]. This collection, named Didactic Gospel (Evangelie uchitel'noe), instead of being attributed to the Patriarch of Constantinople John IX Agapetus (1111-1134), was mistakenly considered as belonging to Patriarch Callistus I (1350-1353, 1355-1363/4), in the

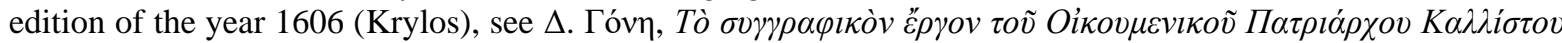
$A^{\prime}$, 'A $\theta \tilde{\eta} v \alpha 1,1980$, pp. 298-309.

${ }^{161}$ BRV, I, pp. 91-92.

${ }^{162}$ Urs, Diaconul Coresi, p. 210.

${ }^{163}$ It has been affirmed, in the same literature, that deacon Coresi got help, considering the large volume of the book, and the number of copies of this edition, from several printer disciples, who seem to have included S,erban, his son, and clerk Marien, although they are not mentioned in the Prologue (Urs, Diaconul Coresi, p. 210).

${ }^{164}$ Urs, Diaconul Coresi, p. 209.

165 Gheţie - Mareş, Diaconul Coresi, pp. 111-112; see also Urs, Diaconul Coresi, p. 208.

${ }^{166}$ Ivaşcu, Istoria, p. 107.

${ }^{167}$ See Gaftoi-Holtea, Mitropolitul Varlaam, pp. 192-193; Păcurariu, Istoria Bisericii, I, p. 483; Ion I. Croitoru, “Alte contribuții ale Sfântului Varlaam († 1657), mitropolitul Moldovei (1632-1653), la apărarea învățăturii ortodoxe în fața Protestantismului”, in Croitoru, Ortodoxia şi Apusul, II, p. 669, note 31 (hereinafter: Croitoru, Alte contribuții).

168 The first sermon is to the Sunday of the Publican and the Pharisee, and the last sermon is to the feast of the Beheading of Saint John the Baptist, namely to the day of 29 August (Urs, Diaconul Coresi, p. 205). The series of sermons is ordered after the Preface, see Diaconul Coresi, Carte cu învățătură (1581), published by Sextil Pușcariu, vol. I, Textul, București, 1914, pp. 23-37. 
$1540^{169}$. It is considered that the absence of the respective sermons is due to the Slavonic original, containing, with few exceptions, no homilies to the respective Saints, but explanations to the evangelical pericopes meant for those feasts ${ }^{170}$. It is not excluded that these absences from the Slavonic original may have been caused by a protestant influence from the Polish Kingdom, on the one hand, and, on the other hand, they explain the zeal that Lukas Hirscher put in the search of this book, as he mentions in the Preface of the edition of $1581^{171}$, because its structure did not accentuate per se the veneration of the Saints ${ }^{172}$, not hesitating, however, to impose as well, as editor of the book, certain omissions ${ }^{173}$. Actually, this book, having the text of the evangelical pericope before the text of the homily corresponding to it, which represented an innovation of deacon Coresi ${ }^{174}$, was part of the plan meaning to convert the Romanians to the Reformation, for whose realization the Lutheran Pastor Johannes Scherer-Nyirő had been called to Brașov, who undertook an energetic propaganda, during the period $1579-1581^{175}$.

Despite these shortcomings, unnoticed, seemingly, at that time, by any hierarch of the Orthodox Church, the book was received by the Romanians and disseminated among them, a fact mentioned by Lukas Hirscher, who states, in a recommendation letter for this book of 14 August 1582 addressed to the judge of Bistriţa, Gáspár Budecker, proposing to him to sell it to the Romanians of the respective area, that this book is sought after by the rulers of Wallachia and Moldavia who, by their bishops, are buying it and introducing it in their countries $^{176}$.

Simultaneously to this period of Lutheran propaganda via the printing press, the proselytist Calvinist action began, aimed at attracting the Romanians to the new doctrine and at magyarizing them, by taking measures such as the designation of Calvinist-Romanian bishops or superintendents, by summoning Calvinist councils (synods), by printing books in Romanian containing Calvinist ideas and teachings ${ }^{177}$.

The context was created to favor the Calvinist superintendents. They enjoyed the support of the political authority of the Principality, which also designated them, being

\footnotetext{
${ }^{169}$ Scorpan, Locul Cazaniei lui Varlaam, p. 552; Păcurariu, Istoria Bisericii, I, pp. 483, 489 (bibliography); Gaftoi-Holtea, Mitropolitul Varlaam, pp. 192-193.

${ }^{170}$ Gaftoi-Holtea, Mitropolitul Varlaam, pp. 135-136.

${ }^{171}$ BRV, I, p. 91.

${ }^{172}$ It has been noticed, concerning the Zabludów edition, that in the second part, entitled Teachings to the Great Feasts and the Celebration of the Chosen Saints, no hagiographic homilies can be found, but only evangelical pericopes, accompanied by their interpretation (Gaftoi-Holtea, Mitropolitul Varlaam, pp. 135-136). In this way, was accentuated per se to a lesser extent the veneration of the Saints, mentioned only in the titles of the Teachings, and was underlined to a greater extent the use of the Holy Scripture, in other words, this was an indirect reference to the protestant principle sola Scriptura and the Holy Tradition was ignored (Croitoru, Alte contribuții, pp. 669-670, notes 32-33).

${ }^{173}$ Croitoru, Propaganda protestantă, p. 479, note 75.

${ }^{174}$ Introduced by him as well in The Interpretation of the Gospels, namely in two books edited precisely by the Protestants. This procedure will be met in the Ukrainian editions only simultaneously with "The Gospels with teaching" ("Didactic Gospels") printed in 1616 (at Yevie) and in 1637 (at Kiev), see D. H. Mazilu, Proza oratorică în literatura română veche, II, București, 1987, pp. 37-37; Gaftoi-Holtea, Mitropolitul Varlaam, p. 167; Croitoru, Alte contribuții, p. 670, note 33.

175 Gheţie - Mareş, Diaconul Coresi, p. 113; Urs, Diaconul Coresi, p. 209.

${ }^{176}$ Hurmuzaki, XI, p. 656; Scorpan, Locul Cazaniei lui Varlaam, p. 555; Păcurariu, Istoria Bisericii, I, p. 479; Urs, Diaconul Coresi, p. 275. For the analysis of the Orthodox content of this book, see I. Turcu, "Evanghelia cu învăţătură din anul 1581 - consideraţii, precizări, accente - ”, in Biserica Ortodoxă Română 99/7-8 (1981), pp. 888-911.

177 Păcurariu, Istoria Bisericii româneşti din Transilvania, p. 125.
} 
recruited from among the Romanians lured into joining the Calvinism and whose names were then magyarized. The purpose of the superintendents was to enact the measures taken for the calvinization of the Romanians and they were undertaking their activity by the side of the Orthodox hierarchs who, together with the Romanian Orthodox clergy and believers, were obliged to submit to and honor the superintendents, because, otherwise, they were punished $^{178}$. Actually, the designation of a superintendent over the Orthodox clergy and believers corresponded to a new strategy of the Calvinists who, noticing that the Romanians cannot be attracted to the Reformation with the help of the Calvinist preachers and pastors, as they had proceeded for the Roman-Catholic populations, wished, in the case of the Romanians, to succeed in the same thing by means of the Orthodox hierarchy and priests who were shepherding them ${ }^{179}$.

At the same time with the start of the Calvinist propaganda, following the editorial association of deacon Coresi with the Hungarian noble Miklós Forró of Háporton, two books in one volume were printed in Romanian, probably in 1567 or 1568 , according to some in Braşov, according to others in Teiuş, Alba Iulia, Cluj, Aiud or Abrud, all these localities representing, however, important Calvinist centres ${ }^{180}$, in the specialized literature finally standing out the locality Alba Iulia ${ }^{181}$. It is supposed that after the collaboration with Miklós Forró ("Foro Miclăuș" according to his designation by Coresi ${ }^{182}$ ), since the printed titles received no credit because they were considered heretic and poisonous, deacon Coresi moves on to a printing activity on his own, during the period $1570-1581^{183}$. Yet, as we mentioned above as well, some researchers deny Coresi's independent activity as a printer starting with the years 1569-1570 and until the end of his eartly life (c. 1583), leaving open to future research the question whether or not he was completely independent starting with 1570 , when it is attested that he had a printing press of his own, or was an employee of the Saxon printing press founded by Honterus, with some moments of independence, leading the

178 Croitoru, Propaganda protestantă, p. 479. The first known superintendent was Gheorghe (George) of Sângeorz (1566-1568), and, for him, it was decided, in the Diet of Sibiu (30 November 1566), that those of the Romanians who do not honor him as they ought shall be punished as traitors, an accusation that triggered the confiscation of their fortune, and the Orthodox heresy shall be removed from among them, while the Orthodox bishops, priests and believers who will not pass to the true religion, namely to Calvinism, shall be forced to leave Transylvania. The respective decision did not lead to the result expected, because the Romanians did not let themselves convinced to embrace Calvinism, while the nobility, even those who were Calvinists, had no interest in expelling the Romanians, who were almost the only labour force on their estates. The measures taken by the superintendent and the authorities in 1567 did not trigger the result hoped for, because at the Diet of Turda (June 1568) it was noticed that there are still very many Romanians in the country who do not submit themselves to the Calvinist bishop, but listen to their old priests, requesting, therefore, their punishment (Meteş, Istoria Bisericii, p. 83; Croitoru, Propaganda protestantă, p. 480).

${ }^{179}$ Crăciun, Protestantism şi Ortodoxie, p. 40.

${ }^{180}$ See Păcurariu, Istoria Bisericii, I, p. 480; Dan Horia Mazilu, Recitind literatura română veche, 1, Bucureşti, 1994, p. 179; Binder - Huttmann, Datarea și geneza Cazaniei I, pp. 109-117; Gheție, Studiu introductiv, p. 11; Al. Mareş, "Când şi unde s-au tipărit Tâlcul Evangheliilor şi Molitevnicul rumânesc?", in Limba română 16/2 (1967), pp. 119-127; Gheţie - Mareş, Diaconul Coresi, p. 118; Urs, Diaconul Coresi, pp. 172-173. It ought to be mentioned that in the Romanian historiography has been proposed as printing date for the respective volume also the year 1564 (Istoria literaturii române, I, p. 310; Ivaşcu, Istoria, p. 102; Cartojan, Istoria literaturii, p. 102).

${ }^{181}$ Urs, Diaconul Coresi, pp. 174-175.

182 Coresi, Tâlcul Evangheliilor, p. 187. One can note the fact that although the name Miklós is the correspondent of the name Nicolae in Romanian (Nicholas, in English), deacon Coresi directly romanianizes the Hungarian name, rendering it under the form Miclăuș.

${ }^{183}$ V. Molin, Coresi editor şi tipograf..., pp. 317, 321. 
Romanian section of this printing press ${ }^{184}$. As far as Coresi's own printing press is concerned, until the affirmation or rejection of its existence, some researchers situate it in Şcheii Braşovului, but the latest studies tend to situate the entire printing activity of Coresi inside the fortified city of Braşov ${ }^{185}$.

The first title of the volume printed in 1567 or 1568 was The Interpretation of the Gospels (Tâlcul Evangheliilor) ${ }^{186}$, which comprised ${ }^{187}$ a mixture of Calvinist and Orthodox teachings: predestination, sola fide, rejection of the veneration of the Saints and of the reverence for the holy icons, of the respect for the Church hierarchy, of the monastic life, of the remembrance of the dead etc., along with quotations from the writings of the Holy Fathers (Athanasius the Great, Cyril, John Chrysostom) and words defending fasting, which was, nevertheless, disowned by the Reformation, and in the end a text representing a violent criticism to the superior hierarchy and the lay rulers ${ }^{188}$. It should be mentioned that regarding this criticism deacon Coresi himself felt the need to apologize, writing at the end of the first part of the volume, in the Epilogue entitled Dojana cetitorilor, namely Advice to the Readers, where he also invokes the organs of the Divine Revelation, the Holy Scripture and the Holy Tradition, the latter contested by the Protestants, that where this book scolds the hierarchs, bishops, priests, monks and rulers, it does not scold the good ones, but the bad ones $^{189}$. However, the book, by its content, resulted, according to some researchers, from the collaboration between Miklós Forró, a rich noble who was also very active in the political life of the Principality of Transylvania, and the Calvinist superintendent Gheorghe of Sângeorz ${ }^{190}$, was meant for those who had passed to Calvinism, but also to spread the

${ }^{184}$ Gheție - Mareş, Diaconul Coresi, pp. 45-46, 258.

185 Gheție - Mareş, Diaconul Coresi, pp. 43-44.

${ }^{186}$ For the reprinting of the princeps edition see Coresi, Tâlcul Evangheliilor, pp. 31-187. It is considered that by means of deacon Coresi's printing work, two books of Kazania were printed in the $16^{\text {th }}$ century. For this reason, Tâlcul Evangheliilor (The Interpretation of the Gospels) is cited in the specialized literature, as mentioned above (see note 154), under the title Cazania I (Kazania or Homiliary I), whereas Evanghelia cu invăţătură (The Gospel with teaching) bears the title of Cazania II (Kazania or Homiliary II, see Gheţie, Studiu introductiv, p. 9; see, also, note 154). Regarding the text of Cazania I, it has been affirmed that its translation was realized in the region of Banat and Hunedoara, by an erudite Romanian from the proximity of the Calvinist superintendent Gheorghe of Sângeorz, not being excluded a collaboration of the translator with the Calvinist superintendent and the Hungarian editor Miklós Forró, whereas Coresi was just a master typographer, which shows that the latter's relations with the supporters of the Calvinism were purely commercial. As prototype, a Slavonic text from the first half of the $16^{\text {th }}$ century was used, which was either made up by an Ukrainian Calvinist pastor, or the passages with the Calvinist doctrine were introduced in the respective text at a later time or at the moment of translation (Gheţie, Studiu introductiv, pp. 10, 12-14; Vedinaş, Coresi, pp. 70-71; Gheţie Mareş, Diaconul Coresi, pp. 102-108; see also Al. Mareș, op. cit., pp. 119-130).

${ }^{187}$ According to the habit already noted also in other books printed in the context or under the influence of the Reformation, in The Interpretation of the Gospels was affirmed the necessity of using the Romanian language in the worship (Gheţie, Studiu introductiv, p. 14).

${ }^{188}$ See Istoria literaturii române, I, p. 310; Păcurariu, Istoria Bisericii, I, pp. 481, 488 (bibliography); Gheţie, Studiu introductiv, pp. 14-15; Gheţie - Mareş, Diaconul Coresi, p. 107; Vladimir Drimba, «O copie din secolul al XVII-lea a „Tâlcului evangheliilor” și „Molitevnicului” diaconului Coresi», in Studii și Cercetări de Istorie Literară şi Folclor IV (1955), pp. 538-541.

${ }^{189}$ Coresi, Tâlcul Evangheliilor, p. 187; BRV, I, p. 51; Lupaş, Istoria bisericească, p. 54. In the same Epilogue it is shown that the printing of The Interpretation of the Gospels was preceded by the appearance of Tetraevangelion and of Praxis, namely the Apostolos, so that The Interpretation of the Gospels was a natural consequence, meant to help the Romanians' priests to explain the word of God (Urs, Diaconul Coresi, pp. 176177).

190 At. Popa, “Originalul cântecelor din Molitvenicul tipărit de Coresi în 1564”, in Limba română 15/3 (1966), p. 257 (hereinafter: Popa, Molitvenicul tipărit de Coresi); Urs, Diaconul Coresi, pp. 180-181. 
Calvinist doctrine among the Orthodox Romanians of the Principality ${ }^{191}$, which explains its rejection by the latter, although it had been printed in a beautiful Romanian language ${ }^{192}$. Actually, The Interpretation of the Gospels is considered, even in recent studies, a book related to the Hungarian Calvinist culture and literature ${ }^{193}$.

The second title of the respective volume, printed as annex and entitled Molitevnic rumânesc (Romanian Euchologion), represented, actually, a Book of Calvinist Songs and Services (Carte de cântece şi slujbe calvine), whose compiler or translator is supposed to have been the superintendent Gheorghe of Sângeorz ${ }^{194}$ or a Romanian Calvinist pastor from his proximity ${ }^{195}$, Miklós Forró not being excluded either ${ }^{196}$. However, it has been affirmed that the last was the editor of this book as well, based on whose order deacon Coresi printed the two books in a single volume ${ }^{197}$. After an Introduction (Polojenie, namely Introducere), this compilation, representing, according to the unanimous opinion of the researchers, a product of Calvinism ${ }^{198}$, contained Prayers and the services for Baptism, Crowning, Holy Communion with the Confession of Sins, the Typicon of the Liturgy, Vespers, Matins, Songs in the Psalms and in the Gospels, ending with the Funeral Service $)^{199}$. By this book, the Calvinist superintendent aimed to radically reform the Orthodox worship ${ }^{200}$, in which the number of the Mysteries be reduced only to three (Baptism, Marriage and Communion) ${ }^{201}$, and the forms of cult only to sermon, various hymns and psalms ${ }^{202}$.

The printing of the volume containing the two books at Alba Iulia is explained by the fact that it was desired that the princely residence of Transylvania should become as well a

191 Gheţie, Studiu introductiv, p. 14; Gheţie - Mareş, Diaconul Coresi, p. 108; Croitoru, Propaganda protestantă, p. 481 , note 86 .

192 Vedinaș, Coresi, p. 70.

193 Nagy Levente, “O predică a lui Péter Juhász Melius tradusă în română și rutenă. (Date noi despre sursele Cazaniei I a lui Coresi), in Rodica Zafiu, Adina Dragomirescu, Nicolae Alexandru (editors), Limba română. diacronie și sincronie în studiul limbii române, I, București, 2014, p. 279.

${ }^{194}$ About him, see above note 178.

195 Binder - Huttmann, Datarea și geneza Cazaniei I, p. 117; Gheţie, Studiu introductiv, p. 17.

196 Gheţie - Mareş, Diaconul Coresi, p. 119.

${ }^{197}$ Urs, Diaconul Coresi, p. 187.

198 Gheţie - Mareş, Diaconul Coresi, p. 119; see also Vladimir Drimba, op. cit., pp. 535-538.

199 See Coresi, Tâlcul Evangheliilor şi Molitevnic rumânesc, critical edition by Vladimir Drimba, with an introductory study by Ion Gheție, București, 1998, pp. 189-211 (hereinafter: Coresi, Molitevnic rumânesc); Gheție, Studiu introductiv, p. 15; Urs, Diaconul Coresi, p. 183. Just as in the case of Cazania I, it is considered that the translation of the compilation was done in the area of Banat and Hunedoara. According to the studies made so far, it has been affirmed that the text of the prayers and of the services is a shortened translation from Hungarian of the Agenda printed by Gáspár Heltai in Cluj (1551 and 1559), and the songs are Calvinist texts, taken from different sources, two Calvinist printings being cited: one in Hungarian, The Book of Calvinist Songs of Gergely Szegedi (Cluj, 1562), and another one in Romanian, Carte de cântece (Book of Songs, Cluj, 1571-1575), see Gheţie, Studiu introductiv, p. 16. It is not impossible that the translator of the two books of the volume printed by Coresi may be one and the same person, characterized by the researchers as an erudite Romanian who had the skill of translating religious texts in his maternal language (Gheţie, Studiu introductiv, pp. 14, 17).

${ }^{200}$ Gheție, Studiu introductiv, p. 17; Gheţie - Mareş, Diaconul Coresi, p. 120.

201 Actually, to two, because Marriage was considered a vow with the Calvinists, and the Confession of Sins

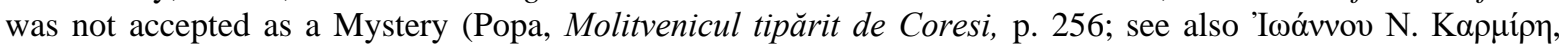

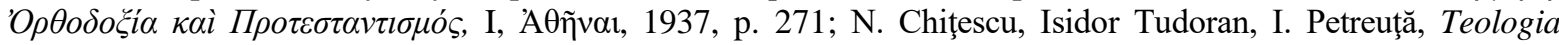
Dogmatică şi Simbolică, II, Bucureşti, 1958, p. 836).

${ }^{202}$ Păcurariu, Istoria Bisericii, I, pp. 481, 488 (bibliography); Popa, Molitvenicul tipărit de Coresi, pp. 255-265; for other details and references to the critical editions of the two books, see Gheţie - Mareş, Diaconul Coresi, pp. 102-108. 
center of radiation for Protestantism, by the direct participation of the Calvinist prince, which shows both the actions based on competition between the Lutherans and Calvinists on the Romanians, and the energetic, sometimes even violent, actions of the Calvinist authorities, aimed at attracting the Romanians to the Calvinist doctrine, taking shape, at that time, as the official religion of the Principality ${ }^{203}$. Actually, the Calvinists adopted a much more radical manner of conversion, unlike the Lutherans, who had a more temperate attitude: the latter print books in Romanian, as a consequence of the decisions made by the City Council of Brașov, and the first apply a plan of mass conversion for the Romanians, as a consequence, however, of the decisions made by the representatives of the Calvinist denomination, who were, at the same time, also the political representatives of the Principality ${ }^{204}$. The context of the emergence of the two books is also inscribed in the spirit of the Council of Teius,, held at the end of the year 1567 or at the beginning of January 1568, when Gheorghe of Sângeorz requested the Romanian priests to receive the teachings of the Reformation, out of which they accept only to begin the divine services in Romanian ${ }^{205}$.

In fact, the attacks against the Orthodox teaching slipped in The Interpretation of the Gospels and their setting into circulation together with the Book of Calvinist Songs and Services triggered an even greater resistance from the Romanians and the priests they had, so that the use of the volume including the two books was limited to the propaganda needs of the Calvinist pastors, being rejected, gradually, by all those who had listened to it only out of necessity ${ }^{206}$. For example, in a Slavonic Euchologion, donated in the year 1569 by Father Dobre to Saint Nicholas Church in Şcheii Braşovului, it was foreseen that if someone wants to come to our faith, then he should renounce all the Latin law and the law of Martin the Heretic and all their heresies and all their calumny by which they defame the Holy Spirit and the Theotokos and God's Saints and the holy icons. Continuing this order, are highlighted precisely the points attacked in The Interpretation of the Gospels: and he shall say: I renounce and say anathema and believe in the Holy Trinity according to God's will and venerate as well the All-Honorable Theotokos forever virgin Mary and all the Saints and the holy persons; and I receive the lent periods and the fasting days: Wednesday and Friday and so I vow before God ${ }^{207}$.

At the request of the Calvinist officials, deacon Coresi's series of printings continued with two more books in Romanian, Psaltirea (the Psalter) and Liturghierul (the Hieratikon or Sluzhebnik), both printed in $1570^{208}$. This date has a double connotation in the specialized historiography, on the one hand, by the measures taken by the representatives of the Calvinist propaganda of the respective year ${ }^{209}$, and, on the other hand, by the affirmation that

\footnotetext{
${ }^{203}$ Urs, Diaconul Coresi, p. 175.

${ }^{204}$ Urs, Diaconul Coresi, p. 181.

205 Urs, Diaconul Coresi, p. 201; Mareș, Introducere, pp. 8-9.

${ }^{206}$ Scorpan, Locul Cazaniei lui Varlaam, p. 551.

${ }^{207}$ Cartojan, Istoria literaturii, pp. 104-105; Croitoru, Propaganda protestantă, p. 484. During the first half of the $17^{\text {th }}$ century, a copier of manuscripts with liturgical texts of Transylvania, Popa Mihai, who also copied a Romanian text defending the Orthodox faith from the Lutheran-Calvinist proselytism, Spunerea legii creştineşti cu răspuns (The Saying of the Christian Law with Answer, 1640-1644), renders in a manuscript (1647) also the divine service of Crowning, in contradiction with the service included in the so-called Romanian Euchologion (Book of Calvinist Songs and Services) of 1567/1568, see I. Turcu, "Popa Mihai, un interesant copist din secolul al XVII-lea”, in Biserica Ortodoxă Română 91/11-12 (1973), pp. 1268-1289.

${ }^{208}$ Mareș, Introducere, pp. 22-23.

${ }^{209}$ See Croitoru, Propaganda protestantă, pp. 482, 485.
} 
during that year or around it, different editions of the two liturgical books were printed, according to some researchers ${ }^{210}$.

The first edition ${ }^{211}$ was realized by deacon Coresi, who printed in Braşov two liturgical books: Psaltirea (Psalter) and Liturghierul (Hieratikon or Sluzhebnik) ${ }^{212}$. It seems that in front of the Romanians' resistance, Prince John II Sigismund Zápolya was willing to make some concessions, renouncing, for the moment, to calvinize the Orthodox worship, as it had been decided in a Council summoned at Aiud (16 October 1569), in exchange for its nationalization, by the committed effort of introduction of the Romanian language in the cult of the Orthodox Church. Based on this new propaganda policy, has been explained the reason why, on the days of 13 and 14 January 1570, the Calvinist superintendent Pavel Tordași or of Turdaş (Hunedoara County) is met in Braşov. He is believed to have concluded in Brașov the agreement for the printing of the two liturgical books ${ }^{213}$, printed at his request in Romanian, as an expression of Prince Sigismund's desire, between 6 February and 1 September $1570^{214}$, without including Calvinist or Lutheran influences, with the evident goal of being accepted by the Orthodox Church, yet constituting, at the same time, elements of nationalization of its worship ${ }^{215}$, as a first and very important step towards the definitive incorporation of the Romanians from Transylvania in the Calvinist movement ${ }^{216}$.

${ }^{210}$ Croitoru, Propaganda protestantă, p. 482.

${ }^{211}$ For the context of the second edition of the homonymous books, printed in Cluj (in the latest specialized studies, the year 1570 has been accepted only for the Psalter, and in the case of the Hieratikon, instead of the year 1570 has been proposed the period of the years 1571-1575), but in Hungarian orthography and with Latin letters, the Hieratikon having a different content, see Croitoru, Propaganda protestantă, pp. 485-486.

${ }^{212}$ BRV, I, pp. 54-56; Păcurariu, Istoria Bisericii, I, pp. 478, 482; Gheţie - Mareş, Diaconul Coresi, pp. 39, 124-125, 132-140; Mareș, Introducere, pp. 24-25. Coresi’s Hieratikon (Liturghier), translated in a hurry, probably in a protestant environment from the area of Banat-Hunedoara or central Transylvania, namely in an area in which the Reformation was strongly spread among the Romanians, shortly before the printing, and after another version in Slavonic than the one printed in 1508, in Târgoviște (Mareș, Introducere, pp. 34-41), comprises only the Service of the Divine Prothesis or Proskomidie and the actual text of the Divine Liturgy of Saint John Chrysostom, with the mention that the Service of the Divine Prothesis begins with Tocmeala slujbei called diacro nstvele, actually representing the ritual of the veneration of the icons (the Service of kairos) and putting on of the priestly vestments (with the washing of the hands), and the end of the Divine Liturgy, which comprised as well the dismissal, has been lost (Mareș, Introducere, pp. 21-22; Urs, Diaconul Coresi, p. 197; for the reediting of this text see Liturghierul lui Coresi, text established, introductory study and index by Al. Mareș, Bucureşti, 1969, pp. 125-148)

${ }^{213}$ Mareș, Introducere, pp. 9, 24, 40-41; Gheţie - Mareş, Diaconul Coresi, pp. 125, 133

${ }^{214}$ Gheţie - Mareş, Diaconul Coresi, pp. 125, 135, 261; Urs, Diaconul Coresi, p. 201.

215 Gheţie - Mareş, Diaconul Coresi, p. 137; Mareș, Introducere, pp. 9-10.

${ }^{216}$ Gheţie - Mareş, Diaconul Coresi, p. 264. According to the data preserved, on 1 September 1570 were sent to the Calvinist superintendent Pavel Tordași the printed copies of the Hieratikon (Liturghier) and, eventually, of the Psalter (Psaltire), which were to be shared to the Romanian priests, on the occasion of the participation to the Small Noel (New Year) at the Council (Synod) of Cluj (1 January 1571), not as a gift, but in exchange for a sum of money from them. A testimony in this sense is the letter of 9 December 1570, sent by Pavel Tordași from Lancrăm (the residence of Pavel Tordași was in Teiuș) to the mayor of Bistrița, with the request to transmit to the Romanian priests, in relation to the above-mentioned Council, to bring money with them to buy the Psalter and the Hieratikon [Documente privitoare la istoria românilor, culese de Eudoxiu Hurmuzaki, vol. XV, Partea I, Acte și scrisori din Arhivele orașelor ardelene (Bistrița, Brașov, Sibiu), publicate după copiile Academiei Române de N. Iorga, 1358-1600, București, 1911, p. 646 (hereinafter: Hurmuzaki, XV, Partea I); Gheţie - Mareş, Diaconul Coresi, pp. 133-134, 323-324; Urs, Diaconul Coresi, pp. 193-194, 275]. This is considered the last action initiated by the Calvinist propaganda among the Romanians under its protector, Sigismund, who died in 1571, leaving the rule of Ardeal into the hands of the Roman-Catholic Stephen IX Báthory (Mareș, Introducere, p. 9). Actually, both Pavel Tordași, and Lukas Hirscher pursued that the books ordered by them be sold mainly among the Romanian priests (Gheţie - Mareş, Diaconul Coresi, $\mathrm{p}$. 
Therefore, the nationalization of the worship was not viewed from the perspective of the promotion of the Romanian language and literature, but with the disguised aim of attracting the Romanians to the Reformation ${ }^{217}$. Actually, the Calvinist superintendent Pavel Tordași, called in the documents of the time Bishop of Romanian language ${ }^{218}$, had received from Prince John II Sigismund Zápolya, who knew Romanian, the task of printing liturgical books in Romanian, among them being the Hieratikon (Liturghier or Sluzhebnik) as well ${ }^{219}$. The same superintendent had convoked, on 16 October 1569, a Council in Teius, for the service of the Liturgy, on this occasion being forbidden the funeral service, whereas the practice of other innovations, unfounded, according to the Calvinists, in the Holy Scripture, is left to the decision of the prince ${ }^{220}$. Moreover, to these one can add the fact that, by the election of Pavel Tordași instead of Gheorghe of Sângeorz, after the latter's death, the Calvinists' attitude regarding the conversion of the Orthodox Romanians becomes more nuanced and more prudent ${ }^{221}$. However, it has been affirmed, in the specialized literature, even though to a lesser extent, that the effort of printing the two liturgical books would be due, more likely, to the demands and needs specific of the Orthodox Church of Transylvania ${ }^{222}$, representing even a cultural work independent of the religious Reformation $^{223}$, a position, nevertheless, contested by many researchers ${ }^{224}$.

It should be mentioned that at the basis of the edition of the Psalter of the year 1570 was another edition, which deacon Coresi printed in Romanian in Brașov, in $1568^{225}$. Its emergence is due to the Calvinist cultural-religious environment, if one has in view the fact that this year is part of the period of intense Calvinist propaganda actions, but, equally likely, it could have been edited as well by the descendants of Johannes or Hans Benkner, if one considers that the Psalter with original, mentioned in the succession act (1585) of Petrus Schirmer's descendants, could be the edition of the Psalter of the year 1568, adding to this last supposition also the fact that Benkner's successors, in their turn, maintained, during the same period, relations of collaboration with deacon Coresi ${ }^{226}$.

Consequently, one can observe several periods of denominational influence and, at the same time, of political exercise over Coresi's printings, realized both in Brașov, and in other protestant propaganda centers .

During the first period, comprised between the years 1560-1565, the printing of the books is due to the proselytism actions promoted by the Saxon Lutherans, who aimed to reform the Church of the Orthodox Romanians, having the support of the Principality's authorities. In this context, four books were printed in Romanian [Catehism (Catechism) or Intrebare creștinească (Christian Question, Brașov, 1560); Tetraevanghel (Tetraevangelion, Brașov, 1561); Pravila Sfinților Apostoli or Sfinților Părinți (Pravila or The Nomocanon of

332). The letter of 9 December 1570, mentioned above, can be regarded as well as an obligatory order, due, probably, to the Romanian Orthodox priests' refusal to buy the two liturgical books, during the time elapsed since their printing until the respective date (Urs, Diaconul Coresi, p. 278).

217 Plămădeală, Dascăli, p. 81; Virgil Molin, "Despre diaconul Coresi. La 400 de ani de la începutul activității de la Brașov și de la tipărirea primei cărți românești”, in Glasul Bisericii 8/7-12 (1959), p. 647.

${ }^{218}$ Hurmuzaki, XV, Partea I, p. 635; Urs, Diaconul Coresi, p. 200.

${ }^{219}$ Urs, Diaconul Coresi, p. 200.

${ }^{220}$ Urs, Diaconul Coresi, p. 201.

${ }^{221}$ Gheţie, Studiu introductiv, p. 17; Gheţie - Mareş, Diaconul Coresi, pp. 120, 264.

222 See Păcurariu, Istoria Bisericii, I, p. 482.

${ }^{223}$ P. P. Panaitescu, Inceputurile şi biruinţa scrisului în limba română, Bucureşti, 1965, p. 163.

${ }^{224}$ Gheţie - Mareş, Diaconul Coresi, p. 137.

225 Urs, Diaconul Coresi, p. 192.

${ }^{226}$ Urs, Diaconul Coresi, p. 189. 
the Holy Apostles or of the Holy Fathers, Braşov, 1560-1562); Lucrul apostolesc (The Apostolic Work), also called Apostol (Apostolos) or Praxiu (Praxis, Brașov, 1566)] and one in Slavonic [Chetveroevangelie, Brașov, 1562)]. Out of these, all of them had Johannes or Hans Benkner as editor, except for the Apostolos, because he dies in 1565, when the family business is taken over by a member of his family ${ }^{227}$.

During the years 1567-1570, as the second period, the denominational influence over deacon Coresi's printings is that of the Calvinists, having, they too, the support of the political authorities of Transylvania. Four books or five titles are printed in Romanian, out of which a book in two editions, and two titles in just one volume [Tâlcul evangheliilor (The Interpretation of the Gospels) or Cazania I (Kazania or Homiliary I)) and Molitvenic (Euchologion or Trebnik) or Molitevnicul rumânesc (Romanian Euchologion), both in the same volume (Alba Iulia, 1567-1568); Psaltire (Psalter, Brașov, 1568); Psaltire (Psalter, Brașov, 1570); Liturghier (Hieratikon or Sluzhebnic, Brașov, 1570)], to which one can add three more books in Slavonic [Sluzhebnik (1568); Sbornik, I-II (Brașov, 1569); Psaltir (Brașov, 1568-1570)]. In relation to the Romanian books, one can note that all of them promote the replacement of the Orthodox content of the religious books by the Calvinist teaching, and they were printed with the contribution of the Calvinist superintendents Gheorghe of Sângeorz and Pavel Tordași ${ }^{228}$. The main result of the Calvinist propaganda, concerning the nationalization of the Orthodox Church worship, was the printing of the Romanian Hieratikon, of whose edition no copy had remained unsold in 1585, in Brașov, facilitating, it is considered, for the first time in the Romanians' history, the performance of the Divine Liturgy integrally in Romanian ${ }^{229}$.

Since 1570 until 1580, deacon Coresi prints eight books in Slavonic, some in several editions [Psaltir (Brașov, 1572-1573); Great Oktoikh, volume I (Brașov, 1574); Great Oktoikh, volume II (Brașov, 1575); Psaltir (Brașov, 1576); Psaltir (Brașov, 1577); Postnaya Triod (Brașov, 1578); Chetveroevangelie (Brașov, 1579); Sbornik (Sas-Sebeș, 1580)], and a Slavic-Romanian one [Psaltir / Psaltire (Brașov, 1577)]. The printings of this period are, therefore, almost exclusively, in Slavonic, which means that they are Orthodox and this action was the consequence of the religious policy of Stephen IX Báthory, who showed a tolerant attitude to the Orthodox Church of the Romanians from the Principality of Transylvania, without being excluded, yet, also the economic interest of those involved in their printing ${ }^{230}$. The editors of these books are either rulers of Wallachia or Coresi himself ${ }^{231}$.

The last period of deacon Coresi's activity is again under the Lutheran influence, being printed a book in Romanian [Evanghelia cu învățătură (The Gospel with teaching) or Cazania II (Kazania or Homiliary II, Brașov, 1581)] and another one in Slavonic [Chetveroevangelie (Brașov, 1583)]. Their editor is Lukas Hirscher, which explains why the first contains certain protestant influences, and the second is an expression of the book trade practice $^{232}$.

${ }^{227}$ Urs, Diaconul Coresi, p. 106.

${ }^{228}$ Urs, Diaconul Coresi, p. 106.

${ }^{229}$ Mares, Introducere, p. 10.

${ }^{230}$ Urs, Diaconul Coresi, pp. 106-107.

${ }^{231}$ Gheţie - Mareş, Diaconul Coresi, pp. 42, 43; Urs, Diaconul Coresi, p. 106; see also Virgil Molin, "Date noi cu privire la activitatea diaconului Coresi ca editor", in Biserica Ortodoxă Română 81/7-8 (1963), pp. 783-786.

${ }^{232}$ Urs, Diaconul Coresi, p. 107. It should be signaled that during the same period, two disciples of deacon Coresi, the clerks Șerban, his son, and Marien, printed Palia de la Orăștie (Palium or Old Testament of Orăștie, named also Saxopolitan Old Testament), in the years 1581-1582 (the work was begun on 14 November 1581 and was 


\section{CONCLUSIONS}

The protestant innovations noticed in deacon Coresi's printings ${ }^{233}$ explain why neither the liturgical books in Romanian [Liturghier (Hieratikon or Sluzhebnik), Molitvenic (Euchologion)], nor the Romanian translations of the main biblical texts used in the worship [Psaltire (Psalter), Evanghelie (Gospel) and Apostol (Apostolos)] had, since the time of Coresi until the years 1679-1683, in the epoch of the Metropolitans Saint Dosoftei (Dositheos, $†$ 1693) of Moldavia (1671-1674, 1675-1686) and Teodosie (Theodosius) of Wallachia (1668-1672, 1679-1708), any other Romanian edition, even though printing presses of Romanian had been in operation since the period preceding the moment when they were printed ${ }^{234}$. For instance, because of its editing in an environment of protestant propaganda, the Liturghier that had been printed in 1570, but only in part and translated into Romanian after a Slavonic original ${ }^{235}$, will have new editions only during the second half of the $17^{\text {th }}$ century and at the beginning of the next, this time in an Orthodox climate (Moldavia and Wallachia, in 1679 and 1683 , respectively 1706 and $1713^{236}$ ), being translated, however, and printed entirely after the Greek originals ${ }^{237}$. Thus, the Liturghier of deacon Coresi represented the initiative of the Calvinist propagandists, and the Liturghier of Saint Dosoftei, which has two editions (Iași, 1679, 1683 ${ }^{238}$ ), was the result of an Orthodox initiative ${ }^{239}$. In exchange, metropolitan Teodosie blesses an edition of the Liturghier, printed in 1680, but with the actual text in Slavonic and only the typiconal indications in Romanian. The motivation is shown by Metropolitan Teodosie himself in the Preface of the respective edition ${ }^{240}$, explaining the refusal to translate the liturgical books in Romanian as solidarity to the tradition of performing the divine services in Slavonic, and as a means of preserving the Orthodox dogma, under the form of the Slavonic expression, in front of the protestant propaganda ${ }^{241}$. These facts are interpreted as representing the attitude of rejection and of defense against the heresies arrived by means of the Romanian books printed in Brașov,

concluded on 14 July 1582), which comprised the first two books of the Old Testament in one volume, Bâtiia (Facerea), namely Genesis, and Ishodul (Ieșirea), namely Exodus. The initiative of the translation and of the printing belonged to certain propagators of the Calvinism among the Romanians, headed by Mihail (Michael) Tordași, the new Calvinist superintendent, called the Bishop of the Romanians (Păcurariu, Istoria Bisericii, I, pp. 484-485).

${ }^{233}$ According to some researchers, deacon Coresi did not have the necessary theological knowledge to notice the heretical teachings slipped into the books that he printed (Scorpan, Locul Cazaniei lui Varlaam, pp. 549, 554-555).

${ }^{234}$ N. A. Ursu, "Notă asupra ediţiei”, in Dosoftei, Dumnezăiasca Liturghie 1679, Iaşi, ${ }^{21980, ~ p . ~ X L V I ; ~}$ Croitoru, Propaganda protestantă, p. 483, note 96.

235 As far as the content of the Liturghier printed by deacon Coresi is concerned, see above, note 212. One should mention, however, that in the $17^{\text {th }}$ century, the books printed by Coresi in Slavonic were sold for very high prices, see Gheţie - Mareş, Diaconul Coresi, p. 325.

236 The editions of the years 1706 and 1713 are due to the efforts of Saint Anthim the Iberian, Bishop of Râmnic (1705-1708) and Metropolitan of Wallachia (1708-1716). The first edition appears in Râmnic, in the second part of the Euchologion (BRV, I, p. 541; BRV, IV, p. 220), being then reproduced separately, with improvements regarding the translation of the texts from Greek into Romanian, in Târgoviște, under the title The Divine Liturgies (Dumnezeieștile Liturghii, BRV, I, p. 487).

${ }^{237}$ Croitoru, Propaganda protestantă, p. 484, note 96.

238 The first edition of the Liturghier of 1679 is entitled Dumnezăiasca Liturghie (The Divine Liturgy, BRV, I, p. 222), while that of 1683 has the title Liturghie și rugăciuni (Liturgy and Prayers, BRV, I, p. 262).

${ }^{239}$ Gheţie - Mareş, Diaconul Coresi, p. 138.

${ }^{240}$ BRV, I, p. 234.

${ }^{241}$ Urs, Diaconul Coresi, p. 279. 
which shows that the nationalization of the worship, by the printing activity from this locality, was regarded as an idea foreign to the mentality and conceptions of the Orthodox Romanians of that period ${ }^{242}$.

The repeated exhortations, found in the Prefaces and Epilogues of the Coresian books, and addressed to the receivers to first read the books, to be sure of their canonicity, and not to judge lightly those who contributed to their printing, constitute, according to some researchers, a decisive argument to illustrate the hostile attitude that Coresi's contemporaries had towards him and his printings. This attitude was also due to the fact that in the respective Prefaces and Epilogues Coresi affirms that he printed the book, which could let one understand that he was a promoter of the introduction of the new denominations in Transylvania, at the exhortation of the representatives of Lutheranism and Calvinism, being paid by the latter ${ }^{243}$. Moreover, Coresi printed the liturgical books in Romanian without the official agreement of the Orthodox Church of the Romanian Countries, having in his action, as grounds, the Reformation principle of transmitting the word of God in the language specific of each nation ${ }^{244}$, but also the tradition of translation and transmission of Jesus Christ's teachings in the spoken language, specific of the Orthodox Church. Actually, deacon Coresi was not able to use, in order to justify the Romanian translations patronized by the Lutherans and the Calvinists, the argument of the tradition, as Saint Dosoftei will do in the Prefaces of the two editions of the Liturghier, which he prepared and printed in Iași ${ }^{245}$, but only the scriptural argument ${ }^{246}$, along with other arguments of practical nature, for instance that it may meet any believer's inner need to understand ${ }^{247}$. However, the phenomenon of printing books in Romanian, which had sprouted in Transylvania, by the printings of Filip the Moldavian and Coresi, will open the way to a long series of printings in Romanian, realized along the $17^{\text {th }}$ century. For example, at the moment of the printing in Romanian of the works Pravila de la Govora (Pravila or The Nomocanon of Govora, 1640 / 1641), Sapte Taine ale Bisericii (Seven Church Mysteries) or Pravilă pre scurt aleasă (Pravila or Chosen Nomocanon in Brief, Iaşi, 1644), Carte românească de învățătură de la pravilele împărăteşti şi de la alte giudeațe (Romanian Didactic Book from the Imperial

${ }^{242}$ Urs, Diaconul Coresi, p. 279. It was necessary to obtain, in order to take this step, the agreement of the Ecumenical Patriarchate, in order for the respective movement not to be considered an innovation, which is why Metropolitan Teodosie, as a representative of an eparchy canonically submitted to Constantinople, affirms, in the same Preface, about the action of translation of the books in Romanian, paraphrasing that he neither wanted, nor dared to accept it, although the same Metropolitan had patronized the edition of the Bucharest Bible (Biblia de la București), in 1688, for which a Preface had been obtained, however, signed by the Patriarch Dositheos of Jerusalem [Metropolitan Teodosie expresses himself in his specific manner by the words: nice am vrutŭ, nice am cutezat (BRV, I, p. 234); Urs, Diaconul Coresi, p. 279; Mareș, Introducere, p. 41; Plămădeală, Dascăli, p. 79)]; regarding other hostile attitudes in the epoch see Urs, Diaconul Coresi, pp. 279-280.

${ }^{243}$ Urs, Diaconul Coresi, p. 279.

${ }^{244}$ Urs, Diaconul Coresi, p. 280.

${ }^{245}$ Saint Dosoftei, as a testimony that it is not forbidden to sing the liturgy in Romanian (Liturghie și rugăciuni, Iași, 1683, în $B R V$, I, p. 263), invokes the positive answer, based on the text of Romans 3: 29, which Theodore IV Balsamon, Patriarch of Antioch (1189 - post 1195), gave to the question of Mark III, Patriarch of Alexandria (1195-1209), whether the priests of Syria, Armenia and other Orthodox countries can perform the divine service in their own languages. Saint Dosoftei also uses other arguments to give authority to the printings in Romanian in front of the reactions of certain conservatist circles, see Croitoru, Folosirea tiparului, pp. 722 723.

246 As he did, for instance, in the Epilogues of the books Tetraevanghel românesc (Romanian Tetraevangelion, Brașov, 1561; BRV, I, pp. 44-45), Psaltire românească (Romanian Psalter, Brașov, 1570; BRV, I, pp. 55-56), Psaltire slavo-română (Slavic-Romanian Psalter, Brașov, 1577; BRV, I, pp. 63-64) etc.

${ }^{247}$ See Plămădeală, Dascăli, pp. 71-72, 81 . 
Nomocanons and other Judgments) or Pravila lui Vasile Lupu (Pravila or The Nomocanon of Vasile Lupu, Iaşi, 1646) and Indreptarea legii (The Straightening of the Law, Târgovişte, 1652), meant to apply the church canon law in the Romanian society, not just as simple juridical bodies, but especially as a guide of spiritual life and moral behaviour, spread both in Wallachia and Moldavia, and in Transylvania, it was known that in the Principality, namely in Transylvania had circulated an edition in Romanian of a Pravila or Nomocanon of the Holy Fathers (Pravilă a Sfinţilor Părinţi, Braşov, 1560-1562), printed by deacon Coresi $^{248}$. At the same time, in relation to the same printing of Coresi, it is also written the fact that following the Wallachian mission to Alba Iulia (May 1640), led by the Wallachian Metropolitan Teofil (Theophilus, 1636-1648), an edition of the Pravila of Govora is also printed for the needs of the priests of the Metropolitanate of Transylvania, edition in which the name of Teofil was replaced by that of Ghenadie (Ghenadius), by God's mercy, Archbishop and Metropolitan of the entire Country of Ardeal or of Transylvania ${ }^{249}$. It is considered that the printing of the respective edition at Govora Monastery, in Wallachia, was due to the intervention of Metropolitan Ghenadie II (1627-1640), who needed such a book instead of the one, sold out, of deacon Coresi, and the gesture of Metropolitan Teofil was also a consequence of his quality of exarch of Neighborhoods (exarh al Plaiurilor) ${ }^{250}$.

Actually, with the help arrived from Wallachia, Metropolitan Ghenadie II also managed to set up a printing press in Alba Iulia. In this hand press was printed, in 1641, with the help of Saint Ilie (Elias) Iorest (1600-1678), Metropolitan of Transylvania (1640-1643) and successor of Ghenadie II, the Evanghelia cu învăţătură (The Gospel with teaching or Didactic Gospel), which represented a republication, however, with many mistakes and shortcomings, of the work bearing the same title, printed by deacon Coresi in $1581^{251}$, an editorial act illustrating the effort of the two hierarchs for the continuation of the work of promotion of the worship in Romanian ${ }^{252}$. It should be mentioned, on the one hand, that out of all Coresi's printings, the Evanghelia cu învăţătură (The Gospel with teaching) or Cazania II (Kazania or Homiliary II) was the only text reprinted, the others enjoying, however, a wide circulation in manuscript ${ }^{253}$. On the other hand, not even the republication of The Gospel with teaching at Alba Iulia had escaped, therefore, the protestant influences ${ }^{254}$, so that the need of the Orthodox believers to have a unitary book, containing the truths of the Orthodox faith with no additions or protestant infiltrations, contributed to the decision of

\footnotetext{
${ }^{248}$ Gheţie - Mareş, Diaconul Coresi, pp. 38, 48, 80-89; Ion I. Croitoru, “Ortodoxie și Ecumenicitate - politica culturală și de civilizație a românilor în secolul al XVII-lea. 2.1. Ortodoxia - tradiția culturală și de civilizație a românilor”, in Croitoru, Ortodoxia și Apusul, I, p. 130 (hereinafter: Croitoru, Ortodoxie şi Ecumenicitate).

${ }^{249}$ BRV, I, pp. 108-114.

${ }^{250}$ Croitoru, Propaganda protestantă, p. 503, n. 229.

251 Păcurariu, Istoria Bisericii româneşti din Transilvania, p. 153; Ion I. Croitoru, "Biserica Ortodoxă din Transilvania", in Croitoru, Ortodoxia şi Apusul, I, p. 224. These mistakes and shortcomings are due, in part, to the structure of the Slavonic original after which the Romanian translation, edited in 1581, had been made (GaftoiHoltea, Mitropolitul Varlaam, pp. 135-136), as we also mentioned previously (see note 172), but also to the copy of the year 1581 used as a model, from which many pages were missing, a fact explaining a series of omissions present in the edition of the year 1641. To these, one can add the intervention of the protestant propaganda supporters, which would explain the absence from the edition of the year 1641 of the homilies for the feasts with fixed date, which were left aside completely for the period September - 25 December (Scorpan, Locul Cazaniei lui Varlaam, p. 561; Gheţie - Mareş, Diaconul Coresi, p. 307; Croitoru, Propaganda protestantă, p. 504, note 231 ).

${ }^{252}$ Ion I. Croitoru, "Sfântul Ierarh Mărturisitor Ilie Iorest (1600-1678)", in Croitoru, Ortodoxia și Apusul, I, p. 314.

253 See Gheţie - Mareş, Diaconul Coresi, pp. 305-321.

${ }^{254}$ See above, note 251.
} 
Saint Varlaam ( $†$ 1657), Metropolitan of Moldavia (1632-1653), of writing and printing Cartea românească de îvvățătură dumenecele preste an și la praznice împărătești și la svinți mari (Romanian Didactic Book to the Sundays over the Year and to the Royal Feasts and to the Great Saints, Iași, 1643) $)^{255}$.

The first Romanian texts of the Biblie or of the Holy Scripture, printed in Transylvania, will open the way for other editions realized in the $17^{\text {th }}$ century whose translation and editing efforts will be put together in the printing of the Bucharest Bible (Biblia de la București, 1688) ${ }^{256}$. While the first Romanian translations of the books of the Holy Scripture had appeared in the context of the imposition of the nationalization of the worship of the Orthodox Church of Transylvania by the protestant propaganda, others were, however, the reasons for printing this Bible in the Wallachian capital. Addressed to all the Romanians and being attributed for the development of the Romanian language a role similar to the one held by Luther's Bible in the German culture and language ${ }^{257}$, its emergence cannot be explained only invoking denominational or catechetic reasons, or the needs for the worship of the Orthodox Church, but these all come together to the cultural benefit of the hierarchy and of the intellectuals ${ }^{258}$, to which one can add the interest of cultural-political affirmation of the two rulers, Serban Cantacuzino (1679-1688) and Saint Constantine Brâncoveanu, the Martyr (1688-1714), patrons or editors of the two princeps editions of this Bible 259

Under the pressures of the protestant propaganda for not highlighting the veneration owed to the Saints and to the holy icons, important points of the Orthodox teaching, it can be noticed that the number of engravings is lower in the books printed or reedited in Transylvania, both during the $16^{\text {th }}$ century, and during the next. For instance, the Slavonic Sbornik or Prazdnicnaya Mineya / Festal Menaeon (Sas-Sebeş, 1580), printed in two editions and at the request of Metropolitan Ghenadie I of Transylvania, representing the first editorial action undertaken by the Orthodox Metropolitanate of Transylvania during deacon

\footnotetext{
${ }^{255}$ Croitoru, Alte contribuții, pp. 666, 670.

${ }^{256}$ For the texts of the Scripture meant for the worship [Paroemia, Psalms together with the Nine Songs according to the Orthodox tradition, namely fragments of the Old Testament (Exodus XV, Deuteronomy XXXII etc.), Apostolos, Evanghelion or Gospel Book], the translation effort had already been done before 1688, when these books had been printed in Romanian, in separate editions, either bilingual (Slavic-Romanian) or only in Romanian: Tetraevanghel slavo-român (Slavic-Romanian Chetveroevangelie or Tetraevangelion, Sibiu, 15511553), Tetraevanghel (Tetraevangelion, Braşov, 1561), Apostol (Apostolos, Braşov, 1566), Psaltirea românească (Romanian Psalter, Braşov, 1568, 1570), Psaltirea slavo-română (Slavic-Romanian Psalter or Psaltir, Braşov, 1577, the edition of deacon Coresi), Palia de la Orăştie [Palium or Olt Testament of Orăştie, called also Saxopolitan Olt Testament, 1582, included the first two books of the Old Testament, Facerea/Bâtiia (Genesis) and Iesirea/Ishodul (Exodus)], Psaltirea slavo-română (Slavic-Romanian Psalter or Psaltir, Braşov, c. 1589 - the edition printed by clerk Şerban, Coresi's son), Noul Testament (New Testament, Alba Iulia, 1648), Psaltire (Psalter, Alba Iulia, 1649, 1651), Psaltirea în versuri (Psalter in Verses, Uniev, 1673), Psaltirea slavo-română (Slavic-Romanian Psalter or Psaltir, Iaşi, 1680), Paremiile de peste an (Paroemia over the year, Iaşi, 1683), Evanghelie (Evangelion or Gospel Book, Bucureşti, 1682), Apostol (Apostolos, Bucureşti, 1683), see Virgil Cândea, Rațiunea dominantă, Cluj, 1979, pp. 114-115, 119-120; Plămădeală, Dascăli, pp. 218-217, 222, note 2; N. Şerbănescu, "Biblia de la Bucureşti. Trei sute de ani de la apariţie 1688-1988", in Biserica Ortodoxă Română 106/9-10 (1988), p. 79; Gheţie - Mareş, Diaconul Coresi, pp. 37-40, 48; Lajos - Lidia Demény, Carte, tipar și societate, pp. 56-257; Croitoru, Ortodoxie și Ecumenicitate, p. 139; note 94; Urs, Diaconul Coresi, pp. 149-171, 187-194, 213-217.

${ }^{257}$ Plămădeală, Dascăli, p. 220.

258 Virgil Cândea, op. cit., p. 115.

${ }^{259}$ Croitoru, Ortodoxie și Ecumenicitate, pp. 138-139; see also Stela Toma, "Von Coresi zur Bukarester Bibel", in Dacoromania. Jahrbuch für Östliche Latinität 7 (1988), pp. 141-147.
} 
Coresi's activity, contains only seven engravings (Saint Symeon the Stylite, The Birth of the Theotokos, The Holy Cross, Saint John the Theologian, The unbelief of Thomas, The Holy and Great Friday and Saint Nicholas). The models for the engravings are taken after the edition of the Prazdnicnaya Mineya printed in Venice, in 1538, by Božidar Vukovič, and about Coresi it has been affirmed that he had the intention to reproduce all the engravings of the respective edition, a proof in this sense being the white spaces reserved for them ${ }^{260}$, yet, because of the Calvinists' propaganda, he gave up printing them ${ }^{261}$. Despite the protestant influences and innovations promoted by some printings of deacon Coresi, which also shows his connections with the movements created by the Reformation in Transylvania ${ }^{262}$, he has the merit of being considered the first scholar who fought consciously for the introduction of the Romanian language in the Church and for the spreading of knowledge in Romanian ${ }^{263}$, a fact indicating many aspects and consequences: a) continuity and, at the same time, completion of the movement ${ }^{264}$ by which the first books translated in Romanian were initiated; b) spreading of the writing in Romanian; c) initiation of the process of replacement by the Romanian language of the Slavonic language used in the worship of the Orthodox Church of the Romanians and in the chancery of the Reigns of Wallachia and Moldavia; d) contribution to the formation of a unitary Romanian literary and liturgical language; e) need of affirmation of the unity of language, faith and origin of the Romanians of everywhere ${ }^{265}$.

For these considerations, many Romanian scholars and researchers are convinced that the phenomenon of introduction of the Romanian language in the Orthodox Church of the Romanian Countries and, consequently, in the usage of the princely chanceries of the extraCarpathian Romanian Countries does not represent an initiative patronized exclusively by the Lutherans or by the Calvinists, but must be considered as a work emerged as a result of a Romanian, Orthodox initiative, a page of internal history ${ }^{266}$, without ignoring, however, the fact that the first printings in Romanian appear in the environment of Transylvania, agitated by the Reformation ideas, which also imposes the observation that the activity realized by

${ }^{260}$ Gheție - Mareş, Diaconul Coresi, p. 40, 202-210, 276.

${ }^{261}$ Croitoru, Folosirea tiparului, pp. 750-751, note 362.

${ }^{262}$ Lajos - Lidia Demény, Carte, tipar și societate, pp. 329, 339-340 - note 52 (bibliography). It has been affirmed even that Coresi's strongest connection to the Reformation was not denominational, but economic (Vedinaș, Coresi, pp. 53, 56-57, 70-71). A proof in this sense is that there is no record of deacon Coresi having embraced the ideas of the Reformation, to which one can add the relations he had with hierarchs and rulers of the extra-Carpathian Romanian Countries, from whom he received book orders, so that he did not break apart from the Byzantine tradition (Vedinaș, Coresi, p. 62).

263 Păcurariu, Istoria Bisericii, I, p. 485. To reinforce these aspects it has been affirmed clearly that deacon Coresi was not a simple instrument in the hands of the Lutheran Saxons, to accomplish at order a mission foreign to him, but a supporter of the nationalization of the divine service in the Romanian Church, an action that he considered necessary (Gheţie - Mareş, Diaconul Coresi, p. 377).

${ }^{264}$ In the sense that deacon Coresi's merit is to have put together his predecessors and contemporaries' endeavours to realize a literature in their national language. He accomplishes, therefore, the role of a totalizer of efforts and aspirations, and his work, the role of synthesis of initiatives started from various regions of the Romanian territory (Gheție - Mareş, Diaconul Coresi, p. 380). Deacon Coresi completed his forerunners' activity by spreading the Romanian books realized using the printing press in a much greater number compared to the very low number of the manuscript copies. Viewed in this way, deacon Coresi's activity represents a victory of the previous cultural actions by which the Romanian language starts to affirm itself as a language of culture common to the entire Romanian area (Urs, Diaconul Coresi, p. 292).

265 Păcurariu, Istoria Bisericii, I, pp. 485-486; Urs, Diaconul Coresi, p. 289.

${ }^{266}$ P. P. Panaitescu, Inceputurile şi biruinţa scrisului..., p. 150; see also Păcurariu, Istoria Bisericii, I, p. 485; for an analysis of the thesis called the inner impulses compared to the thesis of the external influences, see Plămădeală, Dascăli, pp. 70-84. 
the printer deacon in Brașov does not take place independently from the principles promoted by the Reformation ${ }^{267}$. As far as the formation of the unitary Romanian literary and liturgical language is concerned, one can admit that this process begins with Coresi's printings, and, according to some researchers, he did not impose the Wallachian dialect at the basis of the literary language and did not determine any change of the literary norms from the various regions of Dacoromania, either, in the sense of their wallachianization. The acceptance of the Wallachian dialect as unique Romanian norm will happen later, by the middle of the $18^{\text {th }}$ century $^{268}$. However, for the initiation of the respective process, as well as for the fact that Coresi's printings represent the first texts printed in Romanian, constituting, therefore, the material support from which the study of the Romanian literary language began ${ }^{269}$, deacon Coresi is justly called the father of the Romanian literary language ${ }^{270}$.

By calculating a ratio regarding the geographic dissemination of the books printed by deacon Coresi and his disciples, especially regarding those books realized in the printing center of Brașov, one can see that the most numerous printings in Romanian have been found in Transylvania, whereas in Wallachia the number of the Slavonic printings is greater than the one of the Romanian ones, and in Moldavia one can note a balance between the printing in Romanian and those in Slavonic ${ }^{271}$, the latter having a wide circulation also outside the Romanian area ${ }^{272}$. It should be mentioned that Coresi's printings, both those in Slavonic, and those in Romanian, also enjoyed a circulation in manuscripts, the latter, namely the Romanian printings, being submitted not just to the simple process of copying but also to that of linguistic improvement, contributing, therefore, to the promotion of the written Romanian language, especially in the Church, but also outside $\mathrm{it}^{273}$. However, the fruits of deacon Coresi's work, who acted as an independent typographer, master over his tools, making himself available for diverse commissioner ${ }^{5}$ or backers $^{274}$, benefited the Orthodox believers, not just the Romanian ones, but also the Slavic ones, from everywhere ${ }^{275}$.

Consequently, the protestant propaganda was expecting, through the nationalization of the worship of the Orthodox Church and the printing activity of deacon Coresi, to discover, in the Romanians' conscience, elements able to awaken in them a certain spiritual crisis, which did not happen, because different was the living of the Orthodox faith from all that had been offered, at that time, by the Roman-Catholic doctrine and the outbreak of the Reformation.

\section{BIBLIOGRAPHY:}

[1] Bibliografia românească veche, 1508-1830, vol. I, edited by Ioan Bianu and Nerva Hodoș, București, 1903; ibidem, vol. IV, ed. by Ioan Bianu and Dan Simonescu, București, 1944.

\footnotetext{
${ }^{267}$ Urs, Diaconul Coresi, p. 289.

${ }^{268}$ Gheţie - Mareş, Diaconul Coresi, pp. 371, 374 (note 79 for the bibliography); for bibliographic references about the issue concerning the linguistic aspects of deacon Coresi's printings, see Otilia Urs, "Istoriografia coresiană. Partea a III-a. Bibliografia aspectelor lingvistice ale tipăriturilor coresiene", in Transilvania 9 (2012), pp. 28-32.

${ }^{269}$ Ibidem, p. 28.

${ }^{270}$ Plămădeală, Dascăli, p. 70; Dan Simonescu, "Problema originii limbii literare române și cărțile bisericești", in Studii Teologice 13/9-10 (1961), p. 553.

${ }^{271}$ See Gheție - Mareş, Diaconul Coresi, pp. 325-331; Urs, Diaconul Coresi, p. 276.

${ }^{272}$ See Gheție - Mareş, Diaconul Coresi, pp. 322-340; Urs, Diaconul Coresi, pp. 276-277.

${ }^{273}$ See Gheţie - Mareş, Diaconul Coresi, pp. 305-321; Urs, Diaconul Coresi, pp. 282-285.

274 Gheţie - Mareş, Diaconul Coresi, p. 375.

275 Păcurariu, Istoria Bisericii, I, p. 486.
} 
[2] Binder, Ludwig, "Contribuția lui Johannes Honterus la Reforma din Transilvania", in Mitropolia Ardealului 24/4-6 (1979).

[3] Binder, P. / Huttmann, Arnold, "Cu privire la datarea și geneza Cazaniei I tipărită de diaconul Coresi”, in Limba română 16/2 (1967).

[4] Cartojan, Nicolae, Istoria literaturii române vechi, București, ${ }^{3} 1996$.

[5] Cândea, Virgil, Rațiunea dominantă, Cluj, 1979.

[6] Chițescu, N. / Tudoran, Isidor / Petreuță, I., Teologia Dogmatică și Simbolică, II, București, 1958.

[7] Chivu, Gheorghe / Costinescu, Marian, Bibliografia filologică românească. Secolul al XVI-lea, București, 1974.

[8] Coresi, Diaconul, Carte cu învățătură (1581), published by Sextil Pușcariu, vol. I, Textul, București, 1914.

[9] Idem, Carte cu învățătură (1581), vol. I, Textul, Editura Tipo Moldova, Iași, 2011

[10] Idem, Tâlcul Evangheliilor și Molitevnic rumânesc, critical edition by Vladimir Drimba, with an introductory study by Ion Gheție, București, 1998.

[11] Crăciun, I., Catechismul românesc din 1544 urmat de celelalte catechisme româno-luterane Bârseanu, Sturdzan și Marțian, Sibiu/Cluj, 1945-1946.

[12] Crăciun, Maria, Protestantism și Ortodoxie în Moldova secolului al XVI-lea, Cluj-Napoca, 1996.

[13] Croitoru, Ion I., Ortodoxia și Apusul în tradiția spirituală a românilor. Unitatea Ortodoxiei și apărarea credinței ortodoxe în fața propagandei protestante din secolul al XVII-lea, vol. I-II, Târgoviște, 2012.

[14] Documente privitoare la istoria românilor, culese de Eudoxiu Hurmuzaki, vol. XV, Partea I, Acte și scrisori din Arhivele orașelor ardelene (Bistrița, Brașov, Sibiu), publicate după copiile Academiei Române de N. Iorga, 1358-1600, București, 1911.

[15] Dosoftei, Dumnezăiasca Liturghie 1679, Iași, ${ }^{2} 1980$.

[16] Drimba, Vladimir, «O copie din secolul al XVII-lea a „Tâlcului evangheliilor” și „Molitevnicului” diaconului Coresi», in Studii și Cercetări de Istorie Literară și Folclor IV (1955).

[17] Durandin, C., Histoire des roumains, Paris, 1995.

[18] Erich, Agnes / Vârcolici, Niculina, "Controverse privind tipărirea primei cărți în spațiul românesc. Liturghierul (1508)", in Studii de Biblioteconomie și Știința Informării / Library and Information Science Research 13 (2009).

[19] Eudoxiu de Hurmuzaki, Documente privitoare la Istoria Românilor, vol. XI (1517-1612), Documents collected, annotated and published by Neculaĭ Iorga, Bucuresci, 1900.

[20] Gaftoi-Holtea, Florentina, Mitropolitul Varlaam și Damaschin Studitul, București, 2006.

[21] Gheție, Ion, "Activitatea de traducere și tipărire a cărții românești la Brașov la sfârșitul secolului al XVI-lea", in Limba română 24/6 (1975).

[22] Idem, "Coresi și Reforma în lumina unor interpretări noi", in Studii și cercetări lingvistice 18/2 (1967).

[23] Idem, "Din nou despre sediul braşovean al tipografiei coresiene", in Limba română 39/1 (1990).

[24] Idem, "Sediul brașovean al tipografiei lui Coresi", in Limba română 38/1 (1989).

[25] Idem, "Un Apostol românesc tipărit la Sibiu de Filip Moldoveanul?", in Studii și cercetări de lingvistică 22/5 (1971).

[26] Gheție, Ion / Mareș, Al., Diaconul Coresi şi izbânda scrisului în limba română, București, 1994.

[27] Iidem, Originile scrisului în limba română, București, 1985.

[28] Giurescu, C. C., Transylvania in the History of Romania, An Historical Outline, London, 1972.

[29] Huttmann, Arnold / Binder, Pavel, "Contribuții la biografia lui Filip Moldoveanul, primul tipograf român", in Limbă şi literatură 16 (1968).

[30] Ionescu, I., "Patru sute de ani de la tipărirea Evangheliei cu învățătură de diaconul Coresi la Brașov în 1581 și mesajul ce-1 poartă", in Glasul Bisericii 40/11 (1981).

[31] Istoria literaturii române, I, București, ${ }^{2} 1964$

[32] Ivașcu, George, Istoria literaturii române, I, Bucureșii, 1969.

[33] Lajos, Demény / Demény, Lidia A., Carte, tipar și societate la români în secolul al XVI-lea. Studii, articole, comunicări, București, 1986.

[34] Levente, Nagy, "O predică a lui Péter Juhász Melius tradusă în română și rutenă. (Date noi despre sursele Cazaniei I a lui Coresi), in Rodica Zafiu, Adina Dragomirescu, Nicolae Alexandru (editors), Limba română: diacronie și sincronie în studiul limbii române, I, București, 2014.

[35] Liturghierul lui Coresi, text established, introductory study and index by Al. Mareș, București, 1969.

[36] Lupaș, Ioan, Istoria bisericească a românilor ardeleni, Cluj-Napoca, ${ }^{2} 1995$.

[37] Mareș, Al., "Când a murit Coresi?", in Limba română 21/2 (1972). 
[38] Idem, “Când și unde s-au tipărit Tâlcul Evangheliilor și Molitevnicul rumânesc?", in Limba română $16 / 2(1967)$.

[39] Idem, "În legătură cu activitatea tipografică a diacului Lorinț", in Limba română 19/2 (1970).

[40] Idem, "Note despre Coresi", in Limba română 19/3 (1970).

[41] Mazilu, Dan Horia, Proza oratorică în literatura română veche, II, București, 1987.

[42] Idem, Recitind literatura română veche, 1, București, 1994.

[43] Meteș, Ștefan, Istoria Bisericii și a vieții religioase a românilor din Transilvania și Ungaria, I (până la 1698), Sibiu, ${ }^{2} 1935$.

[44] Idem (Meteș, Etienne), La vie menée par les Roumains en Transylvanie du XVI ${ }^{e}$ au XVIII ${ }^{e}$ siècle, Bucarest, 1938.

[45] Molin, Virgil, “Coresi editor și tipograf”, in Biserica Ortodoxă Română 77/3-4 (1959).

[46] Idem, "Date noi cu privire la activitatea diaconului Coresi ca editor", in Biserica Ortodoxă Română 81/7-8 (1963).

[47] Idem, "Despre diaconul Coresi. La 400 de ani de la începutul activității de la Brașov și de la tipărirea primei cărți românești”, in Glasul Bisericii 8/7-12 (1959).

[48] Idem, «În legătură cu circulația unui „catehism vechi” din veacul XVI», in Biserica Ortodoxă Română 77/3-4 (1960).

[49] Idem, "Tradiția artistică a Moldovei în tipăriturile ieromonahului Macarie", in Mitropolia Moldovei și Sucevei 35/5-6 (1959).

[50] Mușlea, Candid C., Biserica Sfântul Nicolae din Șcheii Brașovului, I, Brașov, 1937.

[51] Nițu, Octavian, "Relațiile dintre «Tipografia Diaconului Coresi» din Șcheii Brașovului și «Tipografia Honteriană» din Cetate”, in Biserica Ortodoxă Română 93/3-4 (1975).

[52] Nussbächer, Gernot, "Tipărituri românești menționate într-un act de partaj din 1585", in Limba română 39/5-6 (1991).

[53] Idem, Din cronici și hrisoave. Contribuții la istoria Transilvaniei, București, 1987.

[54] Idem, Johannes Benkner, Sein Leben und Wirken in Wort und Bild, București, 1983.

[55] Idem, Johannes Honterus, București, 1977.

[56] Olteanu, P., "Les originaux slavo-russes des plus anciennes collections d'homélies roumaines", in Romanoslavica 9 (1963).

[57] Panaitescu, P. P., Începuturile și biruința scrisului în limba română, București, 1965.

[58] Papacostea, Șerban, "Moldova în Epoca Reformei. Contribuție la istoria societății moldovenești în veacul al XVI-lea", in Studii. Revistă de istorie 11/4 (1958).

[59] Păcurariu, Mircea, "Macarie", in Enciclopedia Ortodoxiei Românești, București, 2010.

[60] Idem, Istoria Bisericii Ortodoxe Române, vol. I, Iași, ${ }^{3} 2004$.

[61] Idem, Istoria Bisericii românești din Transilvania, Banat, Crișana și Maramureș, Cluj-Napoca, 1992.

[62] "Personalitatea Diaconului Coresi și rolul lui în cultura românească", in Biserica Ortodoxă Română 77/3-4 (1959).

[63] Petrescu, Victor, "Despre primele tipărituri pe teritoriul românesc în secolul al XVI-lea", in Philologia 57 (2015).

[64] Petroaia, Lucian, "500 de ani de la tipărirea primului liturghier ortodox și a primei cărți pe teritoriul țării noastre: Liturghierul lui Macarie ieromonahul (1508-2008)", in Revista Bibliotecii Naţionale a României 14/2 (2008).

[65] Plămădeală, Antonie, Dascăli de cuget și simțire românească, București, 1981.

[66] Popa, At., "Originalul cântecelor din Molitvenicul tipărit de Coresi în 1564", in Limba română 15/3 (1966)

[67] Pușcariu, Sextil, Istoria literaturii române. Epoca veche, edition arranged by Magdalena Vulpe, postface by Dan C. Mihăilescu, București, 1987.

[68] Rădulescu, Maria, Originalul slav al „Evangheliei cu învățătură” a diaconului Coresi, București, 1959 ,.

[69] Rosetti, Al., "Despre data primelor traduceri românești de cărți religioase și despre curentele literare din secolul al XVI-lea", in Limba română 10/3 (1961).

[70] Scorpan, Gr., "Locul Cazaniei lui Varlaam în vechea noastră literatură omiletică din sec. XVI și XVII”, in Cercetări Istorice (Iași) 13-14/1-2 (1940).

[71] Simonescu, Dan, "Problema originii limbii literare române și cărțile bisericești", in Studii Teologice 13/9-10 (1961).

[72] Șerbănescu, N., "Biblia de la București. Trei sute de ani de la apariţie 1688-1988", in Biserica Ortodoxă Română 106/9-10 (1988). 
[73] Idem, «La 400 de ani de la apariția „Întrebării creștinești”», in Biserica Ortodoxă Română 77/11-12 (1959).

[74] Tetraevanghelul tipărit de Coresi, Brașov 1560-1561, comparat cu Evangheliarul lui Radu de la Mănicești, 1574, an edition arranged by Florica Dimitrescu, București, 1963.

[75] Texte românești din secolul al XVI-lea. I. Catehismul lui Coresi. II. Pravila lui Coresi. III. Fragmentul Todorescu. IV. Glosele Bogdan. V. Prefețe și epiloguri, critical editions by Emanuela Buză, Gheorghe Chivu, Magdalena Georgescu, Ion Gheție, Alexandra Roman Moraru, Florentina Zgraon, coordinator Ion Gheție, București, 1982.

[76] Theodorescu, B., "Personalitatea diaconului Coresi și rolul lui în cultura românească", in Biserica Ortodoxă Română 77/3-4 (1959).

[77] Toma, Stela, "Von Coresi zur Bukarester Bibel", in Dacoromania. Jahrbuch für Östliche Latinität 7 (1988).

[78] Tomescu, Mircea, Istoria cărții românești de la începuturi până la 1918, București, 1968.

[79] Turcu, I., "Evanghelia cu învățătură din anul 1581 - considerații, precizări, accente - ", in Biserica Ortodoxă Română 99/7-8 (1981).

[80] Idem, "Popa Mihai, un interesant copist din secolul al XVII-lea", in Biserica Ortodoxă Română 91/11-12 (1973)

[81] Țilică, Dana Silvia, "Ieromonahul Macarie și începuturile tiparului românesc în studii", in Revista Bibliotecii Nationale a României 14/2 (2008).

[82] Urs, Adela Otilia, Diaconul Coresi. Monografie și antologie de texte. Teză de doctorat, Cluj-Napoca, 2009.

[83] Idem, "Istoriografia coresiană. Partea I. Bibliografia tipăriturilor coresiene", in Transilvania 4 (2012).

[84] Idem, "Istoriografia coresiană. Partea a II-a. Bibliografia vieții și a activității diaconului Coresi”, in Transilvania 8 (2012).

[85] Idem, "Istoriografia coresiană. Partea a III-a. Bibliografia aspectelor lingvistice ale tipăriturilor coresiene", in Transilvania 9 (2012).

[86] Vedinaș, Traian, Coresi, București, 1985.

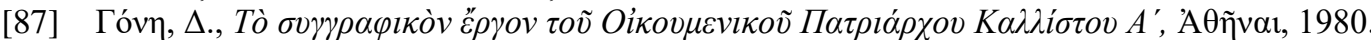

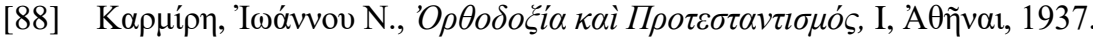

Erratum to: "DEACON CORESI (C. 1510 - C. 1583) AND HIS ACTIVITY AS A PRINTER IN THE CONTEXT OF THE 16TH CENTURY PROTESTANT PROPAGANDA": [ICOANA CREDINTEI. International Journal of Interdisciplinary Scientific Research, No.14 (2021), pp. 37-75].

\section{Additional information}

This study is a translation by the author in English. For the first version of this study in Romanian, with the same title, see Diaconul Coresi - ctitor de limbă română, misionar al credinței străbune și slujitor devotat al neamului românesc, Editura Arhiepiscopiei Târgoviștei, Târgoviște, 2017, pp. 277-328. For the second version, but improved, in Romanian, see Mitropolia Olteniei, no. 69 (821-824)/5-8 (2017), pp. 68-112, which was translated by author in English, with a small change to the title.

This Additional information has now been corrected in the PDF and HTML versions of the Article.

The online version of the corrected article can be found at https://doi.org/10.26520/icoana.2021.14.7.37-75

Published online: June 2021; updated: 09 May 2022. 